\title{
Linking Human Development and the Financial Responsibility of Regions: Combined Index Proposals Using Methods from Data Envelopment Analysis
}

\author{
Diogo Ferraz ${ }^{1,2,3}$. Enzo B. Mariano ${ }^{4}$ Daisy Rebelatto ${ }^{1} \cdot$ Dominik Hartmann ${ }^{1,2,5}$
}

Accepted: 15 April 2020 / Published online: 30 April 2020

(c) The Author(s) 2020

\begin{abstract}
Several indicators on human development and capabilities have been introduced in recent decades that measure the absolute level of deprivations and freedoms of people. However, these indicators typically do not consider to what extent regions and countries efficiently spend their limited financial resources on improving human development. This is an important shortcoming because regions typically face different financial constraints in developing social policies and promoting human development. In this article, we advance methods from data envelopment analysis (DEA) to measure absolute capability values and the social efficiency of 129 Brazilian mesoregions. We present a new indicator called the Capability Index Adjusted by Social Efficiency (CIASE) that evaluates the human development performance of regions based on their absolute levels of deprivations as well as their social efficiency in translating limited financial resources into human development. Moreover, we introduce a Deprivation and Financial Responsibility based Prioritization Index $(D F R P)$ that helps to identify priority regions for higher public expenditures in human development. Our results for the case of Brazil show that several poor regions perform relatively better in terms of social efficiency than in terms of absolute human development. Conversely, several rich regions perform relatively worse in terms of social efficiency than in absolute values. Thus, our analysis shows how DEA methods can help to bridge perspectives that are often presented as separated issues but could be strong allies for development: attending to human deprivation and promoting social efficiency.
\end{abstract}

Keywords Human development - Data envelopment analysis (DEA) - Social efficiency · Financial responsibility $\cdot$ Brazilian mesoregions

\section{Introduction}

The human development and capability approach (HDCA) argue that the expansion of human freedom, and thus the reduction of deprivations and multidimensional poverty, is the essential goal and driver of development (Sen 1982, 1988; UNDP 2016). An extensive

Diogo Ferraz

diogoferraz@alumni.usp.br; dferraz@uni-hohenheim.de

Extended author information available on the last page of the article 
amount of research has shown that focusing on human capabilities and freedom, instead of mere focus on commodities or economic growth, allows for a better understanding of a wide range of social phenomena, such as poverty, inequality, or the quality of life (Sen 1982, 1988; Nussbaum 2000; UNDP 1993, 2016). A number of indicators that are based on human capabilities have been proposed, such as the Human Development Index (HDI), the Human Development Index Adjusted for Inequality (HDIAD), or the Multidimensional Poverty Index (MPI) (UNDP 2016; Ul Haq 1973; Alkire and Foster 2011). These indicators help policy- and decision-makers to compare the absolute level of human development and deprivation in their regions and countries and identify potential bottlenecks.

Nevertheless, these absolute indicators of human development and deprivation do not measure to which extent policy- and decision-makers make good use of limited financial resources for the sake of human development improvements in their region or country (Despotis 2005a, b; Reig-Martínez 2013). Consequently, these absolute indicators do not incorporate some essential aspects of development policies: namely (1) the scarcity of financial resources, (2) the efficiency of development expenditures, and (3) the political willingness of other regions and countries to invest in certain regions based on the perception of an efficient use of their financial support. The human development and capability approach made an important point in emphasizing that income and growth are not the only means and goals of development. Indeed human deprivations, such as hunger or lack of education, are frequently a problem of distribution and institutions rather than that of economic production and wealth (Dreze and Sen 1990). But that does not mean that funding and efficiency do not matter at all. Indeed, efficient use of limited resources that aims at achieving human development could be considered as both a financial and social responsibility (Sen 2009) of countries and regions. In this study, we understand financial responsibility as the ability and political willingness of public authorities to manage limited financial resources in a socially efficient manner, aiming at improving people's capabilities (Frericks and Höppner 2019). It is essential to consider financial responsibility; firstly, because in particular, developing regions tend to have limited financial resources; and secondly, the willingness of financial transfers from other regions depends on the perception of efficient and effective use of their financial funds. If regions and their policyand decision-makers make inefficient use of resources, the willingness of donors or taxpayers from other regions to help a particular region can decline (Timmons and Garfias 2015; Sousa et al. 2017), despite a potential awareness of substantial human deprivations in less developed regions.

Policy- and decision-makers have different means and goals when spending public resources in a given region (Sen 2009; Ballet et al. 2007). For instance, they can invest in infrastructure, education, or economic growth. From a human development perspective, regional and national policymakers have a social responsibility for making choices that increase capabilities of people who elected them. However, despite prioritizing certain goals of development, they also have a financial responsibility to utilize public resources in the most efficient way to achieve these goals. This is especially important in countries with both limited financial resources, endemic levels of corruption, and state inefficiencies. In this regard, it is important to measure social efficiency and, thus, the financial responsibility of public policies. It must be noted, though, that social efficiency and financial responsibility are not only determined by policymakers, but the entire network of socioeconomic agents in a region and country, such as education and research centers, the civil society, and the public and private sectors. They need to work together to achieve high levels of human development (Hartmann 2014). 
Policy emphasis on "promoting human development" (Anand and Sen 2000; Despotis 2005a; Robeyns 2006; Ranis et al. 2006; UNDP 2016) or "improving the efficiency of expenditures" (IMF 2014; Dutu and Sicari 2016; Antonelli and de Bonis 2019) are often discussed separately. In practice, though, focus on human development and efficiency in public expenditures can be valuable allies. A higher level of efficiency can lead to higher levels of human development, and a higher level of human development can lead to a higher level of efficiency and economic growth. When social spending is used efficiently, citizens have faster and better access to public education, hospitals, jobs, and better housing conditions. This improvement in human development can also contribute to economic efficiency and development, as human capital generates benefits for the economy (Ranis et al. 2006). This can lead to a virtuous cycle of human development expansion, as economic development can also contribute to human development and social efficiency. Therefore, policy emphasis should arguably focus not only on human deprivation but also merit the social efficiency and financial responsibility of converting financial resources into human development. It can be argued that an impoverished region that efficiently translates limited financial resources into the best possible outcomes for the local population should be merited and prioritized for development funding. Nevertheless, how can such regions be identified, and thus social efficiency being incentivized?

Methods from Data Envelopment Analysis (DEA) can help to address this difficult question because they allow us to measure both the social efficiency of regions and taking heterogeneous human development strengths and weaknesses of regions into account. DEA uses methods from linear mathematical programming to measure the efficiency of decision units (e.g. in our case regions) to translate inputs (e.g. social expenditures and GDP) into the best possible output levels (e.g. in human development). DEA methods can be used to reveal the maximum number of social outputs that can be produced per unit of GDP and public expenditures to compare countries or regions. Thus, DEA is a suitable method of measuring the social efficiency of regions in converting financial resources into human development. This allows for a better identification of inefficiencies and bottlenecks of regions as well as facilitates learning from comparatively more efficient regions that achieve higher levels of human development with the same or less financial resources.

We apply DEA methods to the case of Brazil, because it is a country with stark socioeconomic contrasts, and thus substantial statistical variance, between more and less developed regions. Several studies showed that Brazil is a country that suffers from heterogeneous problems of multidimensional poverty across its vast territory (Costa et al. 2018; Haddad 2018). This heterogeneity makes it a perfect case to illustrate how methods from DEA can help to analyze different types of absolute human deprivation and social efficiency of regions. It must be noted that a valuable advantage of DEA is that it allows us to assign different weights to strengths and weaknesses of different regions in different dimensions of human development.

This article illustrates how considering both the absolute level of capabilities as well as social efficiency allows for a more comprehensive analysis of the human development achievements of regions and helps to identify priority regions for public expenditure based on both their financial responsibility and need for help. To calculate indices on human development and social efficiency, we use regional data from the last Brazilian Census (IBGE 2010). First, we calculate primary indices to measure absolute performance and relative efficiency. Second, we create composite indicators combining social deprivation and social efficiency. Third, we create two indicators: (a) the Capability Index Adjusted by Social Efficiency (CIASE), to rank regions according to social deprivation and social efficiency; and (b) the Deprivation and Financial Responsibility based Prioritization Index 
(DFRP) to reveal poor regions that show high levels of efficiency. In order to ensure methodological homogeneity, we analyzed both the absolute and relative indices with DEA methods.

It can be argued that regions that show both high levels of human deprivation and high levels of social efficiency merit public investment. Instead, reasons for relatively worse performance in social efficiency in comparison to the human development performance of a region point to the need for in-depth studies on how these regions can use their financial resources more efficiently to reaching their human development potentials. This does not mean that a single analysis of absolute levels of human deprivation or social efficiency is not relevant anymore. Of course, profound levels of human deprivation and severe problems of social efficiency need to be addressed. Nonetheless a joint consideration of both absolute deprivation and social efficiency facilitates valuable new empirical insights, theoretical debates, and applied policy measures on how to promote human development under financial constraints. Moreover, it facilitates identification of strengths, weaknesses and human development improvements potential of regions with weak, medium as well as high levels of human development.

The remainder of this article is structured as follows. Section 2 provides a literature review on absolute measures of human development as well as on social efficiency measures using methods from DEA. Moreover, it discusses the social conditions and regional differences in Brazil. Section 3 introduces the data and our methods, including the creation of two new indicators. Section 4 presents the results, including a sensitivity analysis of the ranking positions of Brazilian mesoregions concerning their DEA capability index (DCI), social efficiency index (SEI), Capability Index Adjusted by Social Efficiency (CIASE), and the Deprivation and Financial Responsibility based Prioritization Index (DFRP). Moreover, we discuss reasons for several case regions changing ranking positions in the respective indicators placing either more emphasis on absolute human development values or social efficiency. Finally, Sect. 5 provides concluding remarks.

\section{Literature Review}

\subsection{Absolute Measures of Human Development and Multidimensional Poverty}

According to the United Nations, human development is a process of enlarging freedoms for all human beings and depends on individuals' capabilities and freedom to achieve functions (Sen 1979, 1980, 1982, 1988; Anand and Sen 1994, 2000; Robeyns 2003, 2005, 2006; UNDP 2016). To estimate this phenomenon in a simple way, the Human Development Index (HDI) is measured as the geometric mean of education, life expectancy, and income (UNDP 2016). However, the HDI has received multiple criticisms. According to Sagar and Najam (1998), the HDI leads to a distorted perspective that is incapable of presenting a comprehensive view of human development dimensions. For Bilbao-Ubillos (2013a), the HDI reflects an average, neglecting population groups that have not benefited from HDI achievements. There are several other issues of criticism and debate, such as the need of composite and qualitative educational measures, income logarithms and adequate normalization processes, as well as the need to consider additional human development dimensions like gender and income inequality, safety and homicides, democracy, environmental variables, refugees' living conditions, and discrimination (Herrero et al. 2010; 
Bilbao-Ubillos 2013a, b; Nussbaum 2000; Fukuda-Parr et al. 2010; Domínguez-Serrano and Blancas 2011; Kaufmann et al. 2008; Grimm et al. 2008; Seth 2009, 2010).

To address these limitations, several studies have developed new indices. For instance, Ranis et al. (2006) expanded HDI to eleven human development dimensions, and FukudaParr et al. (2010) proposed a new indicator with six fundamental rights (health, education, food, housing, social security, and decent employment). Domínguez-Serrano and Blancas (2011) and Kaufmann et al. (2008) introduced the importance of political participation in human development. Grimm et al. (2008) developed a new method incorporating the income distribution effects on human development (based e.g. on the critique of Hicks 1997). Ravallion (2010) reformulated HDI with a cumulative function for education, income, and health, and Herrero et al. (2010) demonstrated that HDI's measurement could be improved.

A recent influential indicator is the Multidimensional Poverty Index (MPI), which looks beyond income to understand how people experience poverty in multiple and simultaneous ways (Alkire and Foster 2011; UNDP 2016). However, MPI also does not appraise financial responsibility and social efficiency. In sum, all of these indicators have focused only on the absolute levels of human development and deprivation. However, these indicators do not consider the social efficiency of regions in translating financial resources into human development.

\subsection{Social Efficiency and Relative Measures of Human Development}

Social efficiency quantifies how efficient regions are in converting financial resources into social welfare (Mariano and Rebelatto 2014). The resulting ranking allows for a comparison of the social efficiency of regions. In contrast to human development indices, the calculation of social efficiency requires the application of more complex methods, such as Data Envelopment Analysis (DEA) and stochastic frontier analysis. These techniques tend to consider either GDP (Despotis 2005a, b; Mariano and Rebelatto 2014) or public expenditures (Davies and Quinlivan 2006; Bilbao-Ubillos 2013a; Wu et al. 2014) as inputs for social development. GDP and public expenditures can be essential factors of human development. Higher levels of GDP might be able to be redistributed and "lift all boats". However, this effect may also depend on public expenditures in health, education, infrastructure, etc.

Despite the growing literature on social efficiency (a structured literature review can be found in Mariano et al. 2015), there are not any studies, to our best knowledge, that combine absolute deprivation and social efficiency aspects. While previous studies focused on absolute deprivation and relative efficiency separately, we argue that both elements must be analyzed together. It must be noted that federal governments often face scarcity of financial resources, requiring authorities to distinguish regions that better merit receiving public investments.

To address both absolute deprivation levels and social efficiency simultaneously, we present here a combined indicator called the Capability Index Adjusted by Social Efficiency (CIASE). This indicator helps policy-makers to identify in areas with both high absolute levels deprivation and merit financial responsibility. We analyzed Brazil, because of its significant regional differences, with the North and Northeast being less developed, and the South and Southeast more developed (de Sousa and Ramos 2017; Monteiro and Lima 2017). 


\subsection{Using DEA to Construct Social Indicators}

Since the work of Hashimoto and Ishikawa (1993), DEA has been employed in social indicators research due to its various advantages. For example, DEA addresses multidimensional efficiency problems, provides a straightforward interpretation in a single index, and attracts the interest of decision-makers (Saisana and Tarantola 2002; Nardo et al. 2005; Boncinelli and Casini 2014; Chaaban et al. 2016). Moreover, in this technique, the weights are defined endogenously, which tackles some of the criticisms of the standard HDI (Sagar and Najam 1998; Wu et al. 2014; Chaaban et al. 2016).

Several human development indices have been derived from DEA. For Mariano et al. (2015), these indices are divided into two categories: (1) composite indices (absolute performance); and (2) social efficiency indices (relative performance). Studies that use this model to evaluate absolute performance are divided into two approaches: (a) the Benefit of the Doubt (BoD) model, which contains outputs and a single input equal to 1 (Bougnol and Dulá 2006; Zhou et al. 2010; Bernini et al. 2013); and (b) models including inputs and outputs that do not express a production relation (e.g. measuring per capita or cost-benefit indicators) (Guardiola and Picazo-Tadeo 2014).

Many works used DEA to measure relative indices of human development. For instance, Mahlberg and Obersteiner (2001) used the Constant Return of Scale (CRS) model with weight restrictions to measure human development. Despotis (2005a, b) analyzed human development in Europe and Asia, utilizing DEA with common weights, while Tofallis (2013) and Zhou et al. (2010) used the multiplicative DEA models to recalculate the HDI. Reig-Martínez (2013) used the Slacks-Based Model (SBM) to evaluate the human development of 42 countries in Europe, North Africa, and the Middle East. Morais et al. (2013) used the Variable Return of Scale (VRS) model to measure the quality of life of 284 European cities.

Several other articles analyzed social efficiency with DEA methods. For instance, Despotis (2005a) constructed a social efficiency index for the countries and found that Canada, Sweden, Japan, the United Kingdom, New Zealand, Spain, and Greece were socially efficient. In an analysis restricted to Asia, Despotis (2005b) found that Fiji, Hong Kong, South Korea, Mongolia, Myanmar, Nepal, Philippines, Solomon Islands, Sri Lanka, and Vietnam were social efficient. Other works, such as Raab and Habib (2007) and Malul et al. (2009), measured efficiency using Gross Domestic Product, Gross National Product, Gini index, and gender performance to compared social efficiency across countries. Morais et al. (2013) calculated social efficiency using GDP per capita as the input and 29 indicators of quality of life as outputs. Mariano and Rebelatto (2014) applied DEA with weight restriction and tiebreaking methods in a global analysis of social efficiency.

\subsection{The Brazilian Challenges to Development}

Despite several studies measuring social efficiency, we did not find works simultaneously analyzing the social deprivations and efficiency values of regions in Brazil. This analysis is crucial because Brazil has managed to decrease poverty and inequality by increasing social expenditures, such as conditional cash-transfer programs, enabling more than 29 million Brazilians to leave poverty between 2003 and 2014 (World Bank 2018). However, Brazil continues to be a highly unequal and structurally heterogeneous country (Hartmann et al. 2019). Moreover, it continues to face bureaucratic, economic, and political inefficiencies, 
and a large number of cases of corruption may undermine the efficiency and effectiveness of social expenditures (Osipian 2013; Sousa et al. 2017).

According to the Oxfam report (2017), corruption negatively impacts public expenditures on health, education, infrastructure, and other projects funded by the government. For example, there are cases of corruption in many public services, such as school meal contracts, procurement of public health supplies, and private business linked to politicians and public enterprises (OXFAM 2017). According to the Federal Court of Accounts (TCU), from R $\$ 100$ billion to R $\$ 300$ billion of public money were embezzled between 1970 and 2016. This amount corresponds to three times the federal government expenditures on education in 2016 (OXFAM 2017). This means it is crucial to consider financial responsibility in Brazil because corruption may negatively affect the Brazilian infrastructure and human development.

Brazil's infrastructure underperforms compared to other emerging economies, due to inefficiencies in the ports and rail system, which reduces its international competitiveness and its exports (Armijo and Rhodes 2017; Marchetti and Wanke 2017; Beuren et al. 2018). The public health and education systems are also criticized as inefficient in terms of financial resources management and quality problems (Araujo et al. 2018). For example, the average performance of students in Brazil is significantly below the OECD average, placing Brazil internationally among the ten bottom positions in science (65th), reading (58th) and mathematics (63rd) in the Program for International Student Assessment (PISA) in 2015 (Pisa 2015).

There are different social realities in Brazil, according to the region in which a person lives. The less-developed North and Northeast comprise states like Maranhão, where only $32.7 \%$ of the population benefit from a garbage collection system, or Rondônia (54\%) where half the population lives without a water supply system, or Piauí where only $8.3 \%$ of the population have access to a sewage system. In contrast, many regions in the South and Southeast have better living conditions. For example, in São Paulo, the wealthiest state of Brazil, almost the entire population has access to a garbage collection (98.8\%), water supply (96.4\%), and sewage system (93\%) (SIDRA 2019).

Despite the better living conditions and absolute indicators in São Paulo, some studies have argued that São Paulo is not efficiently spending its public money. According to Andrett et al. (2018), Sao Paulo's public health expenditures were inefficient in providing vaccination, primary care, hospitalizations, and outpatient care between 2005 and 2014. For Varela et al. (2010), only $6.41 \%$ of the municipalities from the State of São Paulo are efficiently spending public funds in primary health care. Furthermore, Coelho (2018) argues that the wealthiest populations in the municipality of São Paulo tend to benefit more than the poorest from public spending in health. In this sense, the inefficiency in public expenditures reveals how even in developed regions people can be affected by the lack of financial responsibility for human development and social efficiency.

To face this heterogeneity, Brazil has been developing social policies to reduce income inequality, food insecurity, housing deficit, and to raise the federal minimum wage (SaadFilho 2015; Hall 2006; Rocha 2009; Campos and Guilhoto 2017; Maurizio and Vazquez 2016; Brito et al. 2017). However, since the recent corruption scandals, many Brazilians doubt the efficiency of public policies. The federal government has fewer funds, due to the Constitutional Amendment limiting public spending until 2027 (Emenda Constitucional 95/2016). This challenging scenario requires greater financial responsibility to convince Brazilians that social policies generate a higher quality of life. 


\section{Data and Methods}

\subsection{Database}

To evaluate human development and social efficiency in Brazil, we covered five main dimensions represented in 14 social variables from the latest Brazilian census (SIDRA 2019). We justify the choice of Brazil due to the availability of a reliable and comparable census data (Chaaban 2009; Chaaban et al. 2016). This database captures information of 3,734 municipalities and represents $67.18 \%$ of all inhabitants of Brazil in 2010. The municipalities are divided into 129 mesoregions. According to IBGE (2017), a mesoregion is an area within a federal state, which presents an organization of the geographic space defined by the following dimensions: the social process, natural environment, and communication network. These three dimensions enable a space delimited as a mesoregion to have a regional identity. This identity is a reality built up over time by the society that formed in the respective mesoregion.

Since DEA relates all inputs with all outputs, we used GDP and public expenditures as inputs (MPDG 2019) and education and culture, habitation and housing, and health and sanitation as outputs to analyze relative efficiency. The public expenditures are financial resources received from local taxes or the federal government. The outputs represent five dimensions. Education: (a) the number of literate people who are 10 years old or above, (b) number of children attending daycare centers; Housing conditions: (c) number of families with their own houses, (d) number of houses with electricity, (e) number of houses with piped water, (f) number of houses with garbage collection; Health: (g) number of died children per thousand inhabitants(child mortality), (h) number of vaccinated people, (i) life expectancy; Economy: (j) number of people employed, (k) the Gini Index, (l) number of extremely poor people-less than 70.00 Reais $(\mathrm{R} \$)[\mathrm{U} \$ 42.01]^{1}$ (monthly per capita household income in December 2010, according to the World Bank method, Institutions: (m) number of people who voted during the last elections (proxy for democracy), and (n) number of homicides per thousands of inhabitants. The number of homicides per inhabitant is a proxy of the trust and institutions of society. According to Sen (1999), the homicides rate is a proxy for freedom because violence can inhibit people's confidence in society and greatly limit the choices they can make. It is noteworthy that the freedom that comes from the degree of trust in society was called by Sen as "guarantee of transparency" (Sen 1999).

The variables used in this article and the supporting literature are summarized in Table 1.

Following Hashimoto and Ishikawa (1993) and Cook and Zhu (2014), we used a decreasing linear transformation to transform the undesirable outputs (in other words, reverse-coded indicators, e.g., when a higher value means less human capabilities). For example, the children's mortality rate per thousand inhabitants was subtracted from one thousand, and the result can be interpreted as the number of children who survive past the age of 5 years, for every 1000 births. The same was done for extremely poor people and homicides per 1000 inhabitants. To transform the Gini Index, we subtracted its value from 1 (Seiford and Zhu 2002).

\footnotetext{
${ }^{1}$ The values in dollars (U\$) are expressed by the exchange rate of December 30, 2010 (U\$1.00 = R\$1.6662) (Brazilian Central Bank, 2019).
} 
Table 1 Variables used in this study

\begin{tabular}{|c|c|c|c|}
\hline \multicolumn{2}{|l|}{ Variable } & \multirow{2}{*}{$\frac{\text { Dimension }}{\text { General }}$} & \multirow{2}{*}{$\begin{array}{l}\text { Literature review } \\
\text { Morais et al. (2013) }\end{array}$} \\
\hline Inputs & Population & & \\
\hline & GDP & General & Despotis (2005a, b); Ramanathan (2006) \\
\hline & $\begin{array}{l}\text { Public expenditures in education and } \\
\text { culture }\end{array}$ & Education & Varela et al. (2010); Andrett et al. (2018) \\
\hline & Public expenditures in housing & Housing & Varela et al. (2010); Andrett et al. (2018) \\
\hline & $\begin{array}{l}\text { Public expenditures in health and sanita- } \\
\text { tion }\end{array}$ & Health & Varela et al. (2010); Andrett et al. (2018) \\
\hline \multirow[t]{14}{*}{ Outputs } & Literate people & Education & Despotis (2005a,b); Raab et al. (2000) \\
\hline & Children attending daycare centers & Education & Morais et al. (2013) \\
\hline & $\begin{array}{l}\text { Number of families with their own } \\
\text { houses }\end{array}$ & Housing & Morais et al. (2013) \\
\hline & Houses with electricity & Housing & Morais et al. (2013) \\
\hline & Houses with sewage & Housing & Morais et al. (2013) \\
\hline & Houses with garbage collection & Housing & Morais et al. (2013) \\
\hline & Child mortality & Health & Raab et al. (2000); Ramanathan (2006) \\
\hline & Number of people vaccinated & Health & Morais et al. (2013) \\
\hline & Life expectancy & Health & $\begin{array}{l}\text { Despotis }(2005 a, b) \text {; Blancard and Hoarau } \\
\text { (2013) }\end{array}$ \\
\hline & Formal employees & Economy & $\begin{array}{l}\text { Somarriba and Pena (2009); Morais et al. } \\
\text { (2013) }\end{array}$ \\
\hline & Gini index & Economy & Malul et al. (2009) \\
\hline & Extremely poor people & Economy & Malul et al. (2009); Morais et al. (2013) \\
\hline & Number of homicides & Institution & Mariano and Rebelatto 2014; Sen (1999) \\
\hline & Attendance at elections & Institution & Morais et al. (2013) \\
\hline
\end{tabular}

\subsection{Measuring Data Envelopment Analysis (DEA)}

With the 14 social variables, we proceed to measure five different types of DEA-based indicators. We measure an absolute indicator, called DEA Capability Index (DCI), as well as a relative indicator, called Social Efficiency Index (SEI). Moreover, we propose the Capability Index Adjusted by Social Efficiency (CIASE) and the Deprivation and Financial Responsibility based Prioritization Index (DFRP). For the construction of all indicators, we use the Data Envelopment Analysis (DEA) techniques to ensure homogeneity of method and thus receive comparable results, except the Capability Index with Equal Weights (CIEW) as it represents a more traditional way to measure human development.

DEA is a mathematical method based on linear programming developed by Charnes et al. (1978); it measures the efficiency of Decision-Making Units (DMUs) with an empirical linear frontier. DEA reveals the maximum number of social outputs that can be produced per unit of GDP and public expenditures. Thus, it represents the production limit determined by the financial restriction of a region (Cook and Zhu 2014; Mariano and Rebelatto 2014).

According to Cook and Zhu (2014), each region can be ranked according to its efficiency, which varies between zero (no efficiency) and one (full efficiency). To reach the top ranking, DEA maximizes weights, focusing on the strengths of each region (Mariano et al. 2015). DEA models mainly differ according to the type of returns to scale and orientation. The hypothesis of the CRS model considers that outputs vary proportionally to inputs 
Table 2 Main DEA radial models in the form of multipliers. Source: Mariano and Rebelatto (2014, p. 5)

\begin{tabular}{lll}
\hline Model & Input oriented & Output oriented \\
\hline CRS & MAX $\sum_{i=1}^{m} u_{i} \cdot y_{i 0}$ & MIN $\sum_{i=1}^{n} v_{j} \cdot x_{j 0}$ \\
& Subject to: & Subject to: \\
& $\sum_{j=1}^{n} v_{j} \cdot x_{j 0}=1$ & $\sum_{j=1}^{m} u_{i} \cdot y_{i 0}=1$ \\
& $\sum_{i=1}^{m} u_{i} \cdot y_{i k}-\sum_{j=1}^{n} v_{j} \cdot x_{j k} \leq 0$, for $k=1,2, \ldots, h$ & $\sum_{i=1}^{m} u_{i} \cdot y_{i k}-\sum_{j=1}^{n} v_{j} \cdot x_{j k} \leq 0$, for $k=1,2, \ldots, h$ \\
VRS & MAX $\sum_{i=1}^{m} u_{i} \cdot y_{i 0}+w$ & MIN $\sum_{i=1}^{n} v_{j} \cdot x_{j 0}-w$ \\
& Subject to: & Subject to: \\
& $\sum_{j=1}^{n} v_{j} \cdot x_{j 0}=1$ & $\sum_{j=1}^{m} u_{i} \cdot y_{i 0}=1$ \\
& $\sum_{i=1}^{m} u_{i} \cdot y_{i k}-\sum_{j=1}^{n} v_{j} \cdot x_{j k}+w \leq 0$, & $\sum_{i=1}^{m} u_{i} \cdot y_{i k}-\sum_{j=1}^{n} v_{j} \cdot x_{j k}+w \leq 0$, for $k=1,2, \ldots, h$ \\
& for $k=1,2, \ldots, h$ & $w$ without sign restriction \\
& w without sign restriction & \\
\hline
\end{tabular}

Where $x_{j k}$ represents the amount of the GDP $j$ of a region $k ; y_{i k}$ represents the amount of the social dimensions $\mathrm{i}$ of a region $\mathrm{k} ; \mathrm{x}_{\mathrm{j} 0}$ represents the amount of the GDP $\mathrm{j}$ of the region; $\mathrm{y}_{\mathrm{i} 0}$ represents the amount of social variables $i$ of the region; $v_{j}$ represents the weight of the GDP and public expenditures $j$ for the region; $\mathrm{u}_{\mathrm{i}}$ represents the weight of social dimension $\mathrm{i}$ for the region; $\mathrm{m}$ is the quantity of analyzed social dimensions; $\mathrm{n}$ is the quantity of GDP and public expenditures analyzed; and $\mathrm{w}$ represents the scale factor.

(Charnes et al. 1978). On the other hand, the VRS model identifies variation among inputs and outputs, proposing three frontier areas: (a) increasing, where outputs grow proportionately more than inputs; (b) constant, where there is proportionality between inputs and outputs; and (c) decreasing, where outputs grow proportionally less than inputs (Banker et al. 1986). The advantage of VRS models is that it allows for the relative comparison among regions with different financial conditions, as shown in Table 2.

\subsection{Inverted Frontier}

It must be noted that many regions tend to rank the same, thus, they are tied, when applying a traditional DEA approach that emphasizes the strengths of regions. To solve this issue, tie-breaking techniques were developed, such as the Inverted Frontier (IF) method (Angle-Meza and Lins 2002).

The IF was initially proposed by Yamada et al. (1994) and used by Leta et al. (2005) as a tie-breaking function. The Inverted Frontier measures efficiency using inputs instead of outputs and vice versa. This technique brings two interesting findings: (a) an indicator showing region weaknesses, and (b) a frontier of the worst practices.

We used IF as a tie-breaking method for the DCI and SEI. Leta et al. (2005) recommended using a composite index, such as the average between the indicator obtained at the standard frontier $\left(\mathrm{E}_{\text {standard }}\right)$ and the number one minus the indicator obtained with the IF $\left(\mathrm{E}_{\text {Inverted Frontier }}\right)$ (Expression 1).

$$
C I=\gamma^{*} E_{\text {standard }}+(1-\gamma)^{*}\left(1-E_{\text {InvertedFrontier }}\right), \text { with } 0 \leq \alpha \leq 1(1)
$$

The composite index of the classical and inverted boundaries allows for both DEA Capability Index (DCI) and Social Efficiency Index (SEI) to take into account two situations: when regions are compared on the basis of their strongest points (traditional frontier) and when they are compared on the basis of their weakest points (inverted frontier).

We compute the value $\gamma$ equal to 0.5 to aggregate the classical and inverted boundary results (in Expression 1), which means that we used the average between the two 
boundaries. The choice for this value was because it is the most commonly used value in the literature since it tends to be considered a neutral value. However, other values of $\gamma$ could be even more appropriate for this problem. It would be consistent with the capability approach if the inverted border (which highlights the worse performance) had a greater weight than the classical frontier (which highlights the factors where the region stands out most). The reason for this is that the capability approach places great emphasis on setting minimum standards, so it is more important that the region does not perform very poorly on some variable(s) than it performs excellent only in a restricted number of variables. The study of the most appropriate $\gamma$ value, however, is beyond the scope of this paper and requires further in-depth theoretical discussion.

\subsection{Strategy to Compare Absolute Deprivation, Social Efficiency and Financial Responsibility}

Firstly, we measured three primary absolute indicators; all three measures use the same variables but assign different weights to them. The Capability Index with Equal Weights (CIEW) assigns the same weights to each dimension, similar to the standard human development indices. The Capability Index with the Most Favorable Weights (CIMFW) applies a DEA-CRS model using a standard frontier; this means that bigger weights are put on the strengths of regions and lower weights on the weaknesses of regions. The Deprivation Index (DI) uses a DEA-CRS Inverted Frontier, and contrarily to the CIMFW, assigns greater weights to weaknesses and lower weights to strengths. Thus, CIMFW and CIEW are different ways to show the human development of regions, and DI highlights worse social deprivations.

Secondly, with a DEA-VRS model, we measure two relative primary indices. The Standard Social Efficiency (SSE) reveals which regions are more efficient in converting GDP and public expenditures into human development. The choice of DEA-VRS was motivated because this model takes into account the size and scaling of each decision-making unit (macroregion), discriminating the units that have returns of increasing, constant or decreasing scale. This model is the most appropriate because of the heterogeneity of the Brazilian macroregions. Additionally, the Inverted Social Efficiency (ISE) shows which regions are worse at generating human development with their financial resources. Table 3 presents a summary of all primary indicators.

Third, with the help of the primary indices, we created four composite indicators. The DEA Capability Index (DCI), which combines the standard (CIMFW) and the inverted frontier (DI). This absolute indicator allows us to evaluate each region according to their weaknesses and strengths as well as to reduce draws. The Social Efficiency Index (SEI) combines the SSE and ISE and considers the relative efficiency of each region. The SEI also evaluates social efficiency according to the weakness and strengths of each region.

Next, we created the Capability Index Adjusted by Social Efficiency (CIASE) to consider both absolute levels of deprivation and financial responsibility. The CIASE represents a single index, combining the DCI and the SEI. For this reason, CIASE contemplates social deprivation, GDP, and public expenditures together and ranks regions according to their social efficiency (Sen 2009). Simply, CIASE comes up with relevant information to rank regions and to generate policy recommendations (OECD 2008; Zhou et al. 2007).

We tested ten different combinations to evaluate which weights provide a better CIASE representation of the Brazilian regions. For this purpose, we combined DCI and SEI values from 0.1 to 0.9 . It avoids a subjective weighting choice. 


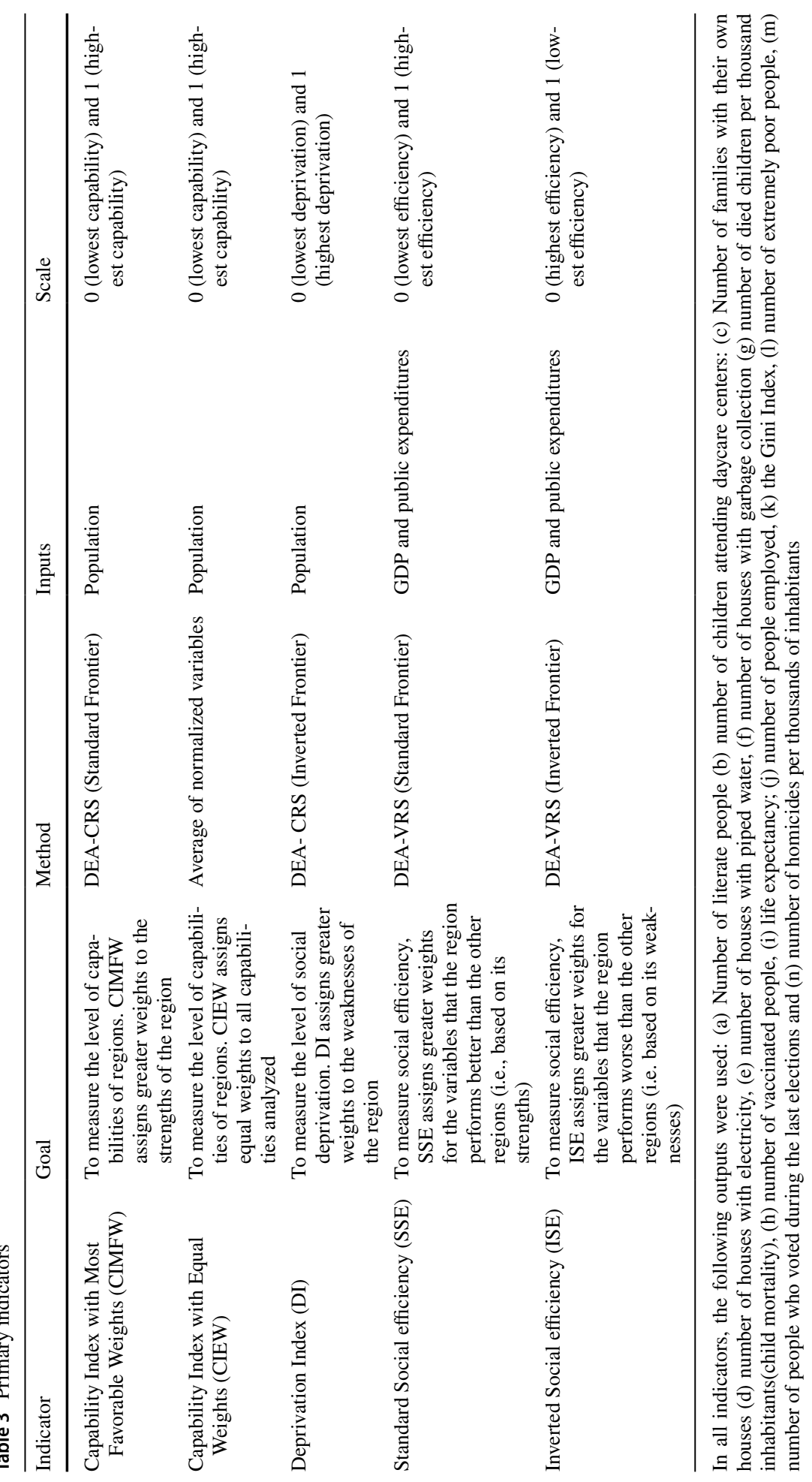


Finally, we created the Deprivation and Financial Responsibility based Prioritization Index (DFRP). The DFRP combines social efficiency (SEI) and social deprivation (DI). This indicator allows policymakers to decide which regions have worse social deprivation and present great social efficiency. In sum, regions with higher DFRP can improve human development using their financial resources efficiently. Table 4 presents a summary of all composite indicators.

Finally, all indicators followed the Min-max normalization method (Expression 2), making them comparable (from zero to one).

$$
\text { Normalized value of } x=\frac{x-\operatorname{Min}(x)}{\operatorname{Max}(x)-\operatorname{Min}(x)}(2)
$$

where $\operatorname{Min}(\mathrm{x})$ and $\operatorname{Max}(\mathrm{x})$ are the minimum and maximum values of the sample.

Besides, our estimates were calculated with Matlab ${ }^{\circledR}$ and Stata ${ }^{\circledR}$, and the graphs were created with the Origin $®$ software.

\subsection{Theoretical and Econometric Validation of Social Efficiency}

DEA is a non-parametric technique, which is used among many other functions, to create social composite indexes and social efficiency indicators. (Charnes et al. 1978; Cook and Zhu 2014). DEA-based composite indices, such as the CIEW and DI, do not have to go through a validation process, but for social efficiency indices, such as the SSE and ISE, this validation plays an important role in indicating that the inputs and outputs have a causal relationship. The studies that used DEA to measure social efficiency (e.g. Morais et al. 2013; Despotis 2005a, b; Mariano and Rebelatto 2014) legitimize the validity of DEA based on the theoretical causal chains between financial means and human development, as well as proof of correlations between at least one of the input and output variables. In this regard, it must be noted that there is strong theoretical and empirical evidence that financial means and human development should at least have some level of correlation. In principle, higher financial means should allow to invest more in health, education, infrastructure etc. A lack of a statistically significant link may not necessarily indicate the lack of a real causal link but rather point to institutional, geographical or factors (such as wars, natural disasters, exploitative institutions, political capture of economic benefits) that hamper the association between higher financial means and human development. Indeed, most human development researchers, including Amartya Sen (1999), do mention economic opportunities as an essential part of human development and the classic human development index (ul Haq 1973) includes income as part of human development. Even though human development researchers tend to focus on human capabilities (e.g. gender equality) as crucial drivers of human development, they also illustrate that there is a significant link between GDP and human development (Ranis et al. 2006). Moreover, several works show that public expenditures in human development (such as expenditures in health or education) are necessary for an increase in capabilities (Azeem Qureshi 2009; Meheus and McIntyre 2017; Mcintyre et al. 2017). In consequence, GDP and social expenditures should be positively associated with human development. The DEA based measures of social efficiency identify the inefficiency in translating financial resources into human development and point to the need to understand the reasons for the lack of efficiency of each case. It is noteworthy that these reasons, such as empowering institutions, political will, or particular differences in historical-geographic conditions, often greatly differ and are hard to measure. The main purpose of DEA is not necessarily to identify and establish the strength of a particular link 


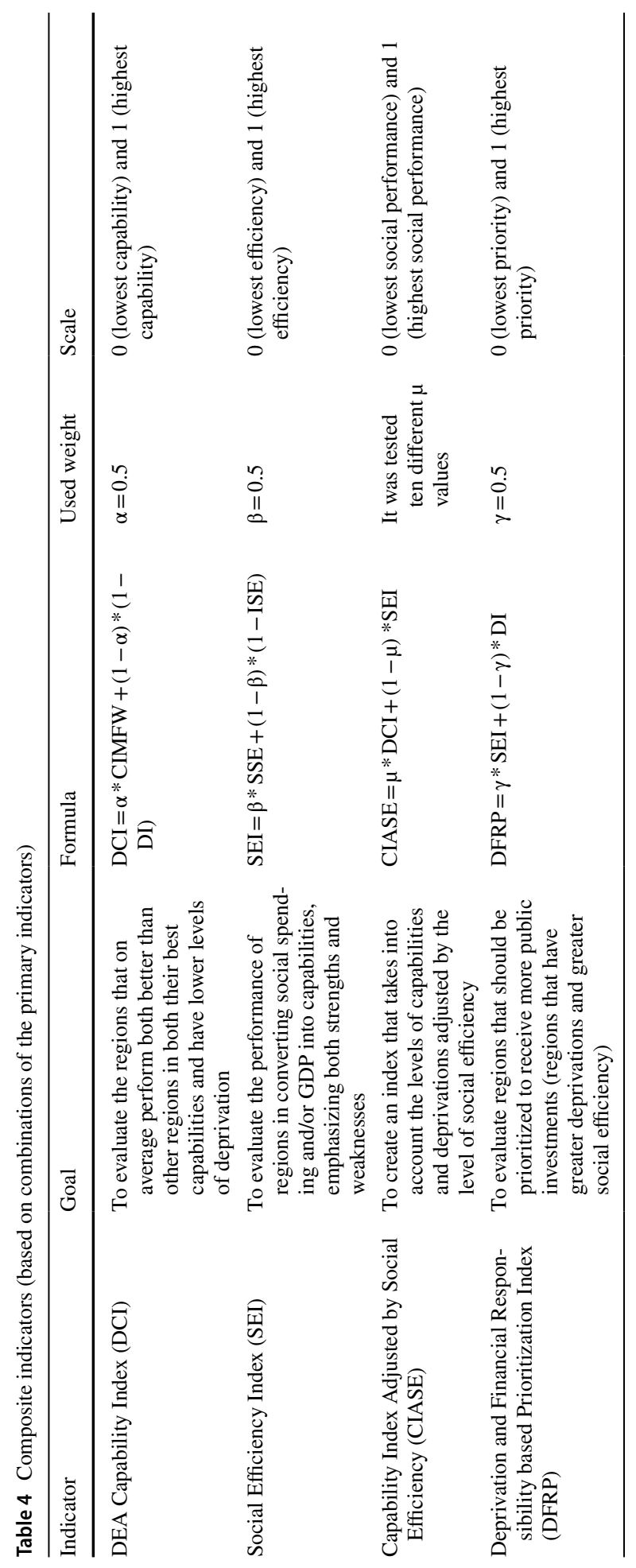


between the input and output variable, as regressions aim to do, but rather identify the variance as it pertains to which regions differ in their ability to translate inputs into outputs.

Despite the legitimation of DEA based on theoretical reasons and its main purpose to (1) reveal the variance, (2) learn from success cases and (3) identify/study problem cases in more detail, our study uses econometric validation to show the correlation between, at least, one input and one output (Golany and Roll 1989). This is in line with previous approaches in DEA, as seen in the works of Mariano and Rebelatto (2014), that validated inputs and outputs through a correlation matrix, and Ferraz et al. (2018) and de Castro Camioto et al. (2014) that used linear regressions to validate DEA inputs and outputs. This is arguably an improvement on most DEA studies that do not use an econometric validation.

We validated our data with fourteen econometric panels fixed-effect models through the Brazilian Census from 2000 and 2010 (IBGE 2000, 2010). For all models, the Hausman test shows fixed effects estimates, while the Breusch-Pagan test did not demonstrate heteroscedasticity, and the VIF test did not detect multicollinearity. The econometric models showed significant associations between several inputs and output variables. These regression estimates and tests are reported in Table 5 ("Appendix I"). It must be noted that it is beyond the purpose and scope of this paper to analyze the causal association and impact strength of GDP and social expenditures on human development in detail. Here we only establish a basic association and focus on differences in the efficiency of translating the available financial resources into human development. Further analysis may also compare the results from DEA and regression residuals approaches in more detail. Nonetheless, we found statistically significant associations between most input and output variables in our basic models, thus validating the DEA procedure not only theoretically (as it is usually done in the DEA literature), but also providing a basic empirical validation that GDP and public expenditures are likely to impact human development.

\section{Results and Discussion}

\subsection{Differences in Absolute and Relative Performance}

The DEA Capability Index (DCI) was used to show which regions are more developed according to their social performance, and the Social Efficiency Index (SEI) measures the relative efficiency of regions. According to the descriptive statistics, the average of DCI (0.497) is slightly lower than the average of SEI (0.544). Furthermore, both DCI (0.475) and SEI (0.536) medians are close to their averages. However, the standard deviation of the DCI values (0.250) is higher than the SEI values (0.209), leading to a greater DCI coefficient of variation (0.503) than the SEI coefficient $(0.383)$.

Figure 1 reveals a significant discrepancy between absolute human development values (DCI) and the social efficiency (SEI) of 129 Brazilian mesoregions. While some regions perform relatively better in absolute terms of human development, other regions perform better in terms of social efficiency, or else other regions have either a good /or bad performance in both indicators.

The Top-5 regions which have a lower ranking when comparing the absolute index and social efficiency are South Maranhense (S MA), North Fluminense (N RJ), South Roraima (S RO), Metropolitan Salvador, and Northeast Baiano (NE BA). These regions present better absolute indicators than social efficiency values. Furthermore, rich regions, such as Metropolitan Macro Paulista (Met Macro Paulista), Vale do Paraíba Paulista (V. do Paraíba 
Paulista), Metropolitan Curitiba (Met Curitiba), Campinas, and Piracicaba have high absolute values but low levels of social efficiency. This suggest that these regions could improve their social indicators by promoting a more efficient use of their relatively high levels of GDP and public expenditures in comparison to poorer regions.

On the other hand, the Top-5 regions which present great social efficiency and worse absolute indices are East Goiano (E GO), South-west Rio-Grandense (SW RS), South Amapá (S AP), Center South Mato-Grossense (CS MT) and South Cearense (S CE). Furthermore, northeastern regions, such as Metropolitan Fortaleza (Met Fortaleza) and Metropolitan Recife (Met Recife), demonstrated a greater degree of financial responsibility of increasing their human development, although they are still suffering from significant social deprivations.

Note that some poor regions in the Midwest, North, and Northeast (S MA, S RR, N GO) achieve (relatively) high levels of social efficiency even though they show high levels of social deprivation. This finding is important because Brazil concentrates public resources in the South and Southeast regions (e.g. Northeast Rio-Grandense and Campinas) and shows lower public expenditures in the North, Northeast, and Midwest regions (e.g. Center South Mato-Grossense, South Cearense, and South Amapá). For example, while the average expenditure in the health is R\$591 [U\$355] per capita in the southern mesoregion $\mathrm{N}$. Rio-Grandense, it is only R \$356 [U \$213] in the northeastern mesoregion S. Cearense, and only R \$302 [U \$181] in the center-western mesoregion C. S. Mato-Grossense. Likewise, while the average expenditure in education and culture in Campinas is R\$567 [U \$340] per person, it is only to R \$286 [U\$171] in the mesoregion South Amapá. In other words, Campinas spent almost double the public money that South Amapá spent to offer educational and cultural services.

The change in ranking positions between DCI and SEI reveals that several regions with relatively high levels of human development perform relatively worse in terms of social efficiency, while several regions with medium to low levels of human development perform relatively better in terms of social efficiency. For instance, while Campinas ranked 54th position in the absolute ranking, it ranks only on the 105th place, according to the social efficiency ranking. Thus, Campinas loses 51 ranking positions due to its financial inefficiency in generating human development. Several other regions exhibit the same behavior, such as South Maranhense (-102), North Fluminense (-85), South Roraima (-83), Metropolitan Macro Paulista ( -57$)$, and Piracicaba $(-27)$. On the other hand, some regions with high levels of social deprivation improved their ranking position in the social efficiency index. This is the case of East Goiano, which moved from 97 to 9 th place $(+88$ positions). Other regions exhibit the same behavior, such as South-west Rio-Grandense $(+87)$, South Amapá (+85), and Center South Mato-Grossense (+84). To assign public resources, it can be argued that both the absolute level of human development as well as the social efficiency of regions in translating financial resources into human development should be considered.

\subsection{Sensitivity Analysis}

In order to define what weights should be attributed to the Capability Index Adjusted by Social Efficiency (CIASE), we analyzed the ranking permutations among the nine models. Figure 2 presents the evolution of the weights between the absolute performance and social efficiency for each Brazilian mesoregion. While Model $1(\mathrm{SEI}=0.1 ; \mathrm{DCI}=0.9)$ 
emphasizes absolute performance and Model $9(\mathrm{SEI}=0.9 ; \mathrm{DCI}=0.1)$ social efficiency, the CIASE is presented by Model $5(\alpha=0.5 ; \beta=0.5)$.

We observe that several top-ranked regions in Model 1 fall steeply until Model 9. For example, Macro Metropolitan Paulista loses 57 positions, from 48th (Model 1) to 105th place (Model 9). This behavior is recurrent for several rich regions, such as Vale do Paraíba Paulista (-50), Campinas (-41), South Coast Paulista (-41), Piracicaba (-26), and Metropolitan Curitiba $(-11)$. It means that some rich regions perform worse concerning their social efficiency.

Conversely, some regions facing high levels of social deprivation improved their ranking position when more emphasis was put on social efficiency. For example, Metropolitan Fortaleza gains 49 positions, from 114th in Model 1 to 65th place in Model 9. Other regions presented the same ranking evolution, such as East Goiano (+97), South Amapá $(+60)$, and South Cearense $(+49)$. Note that a third group changed rankings less, as can be seen in the examples of South Catarinense (0), Metropolitan Recife (+20), Greater Florianópolis $(+25)$, Metropolitan Belém $(+19)$. Figure 3 illustrates the changing position among the models.

The CIASE tackles these divergences ordering regions according to both aspects. For example, the Macro Metropolitan Paulista ranked 65th place, and Metropolitan Fortaleza ranked 99th place in the CIASE index. Moreover, a third group showed fewer ranking changes (e.g. Greater Florianópolis, the 3rd place). The next section discusses the CIASE contribution.

\subsection{CIASE: a Contribution to the Financial Responsibility Analysis}

By combining social deprivation, GDP, and financial constraints of Brazilian mesoregions, the CIASE contributes to the financial responsibility concept. It provides a better understanding of how to allocate public funds to enhance human development, revealing which regions have more merit to receive public money and tackle their social deprivation.

For example, Campinas ranked 54th in the DCI and 105th in the SEI. Using the DCI, Campinas performs better than regions like East Goiano (97th), and Metropolitan Fortaleza (112nd). On the other hand, according to SEI, Campinas has a lower ranking position than the regions East Goiano (9th), Metropolitan Fortaleza (59th). The CIASE contributes to revealing a new ranking, which ranks East Goiano (49th) higher than Campinas (64th) and Metropolitan Fortaleza (99th). In other words, authorities could give credits to East Goiano (e.g. in the form of increased public support from the federal government) because this region faces a worse social deprivation than Campinas and has greater financial responsibility compared to Campinas and Metropolitan Fortaleza.

The same can be observed in regions like Metropolitan Curitiba (DCI $=34$ th; SEI = 96th; CIASE = 53th), and Center South Mato-Grossense (DCI=102nd; SEI=18th; CIASE $=62 \mathrm{nd})$. While the Center-South Mato-Grossense faces worse social deprivation, Metropolitan Curitiba shows less financial responsibility. For this reason, CIASE prioritizes the region Center-South Mato-Grossense over Metropolitan Curitiba, recommending that financial resources should give credit to regions that are more efficient in tackling social deprivation in Brazil. Finally, other regions, such as Metropolitan Belém (DCI = 86th; SEI =90th; CIASE =88th) and the Metropolitan São Paulo (DCI=70th; $\mathrm{SEI}=77 \mathrm{th}$; CIASE $=72 \mathrm{nd}$ ) presented little variance between absolute deprivation and social efficiency. 


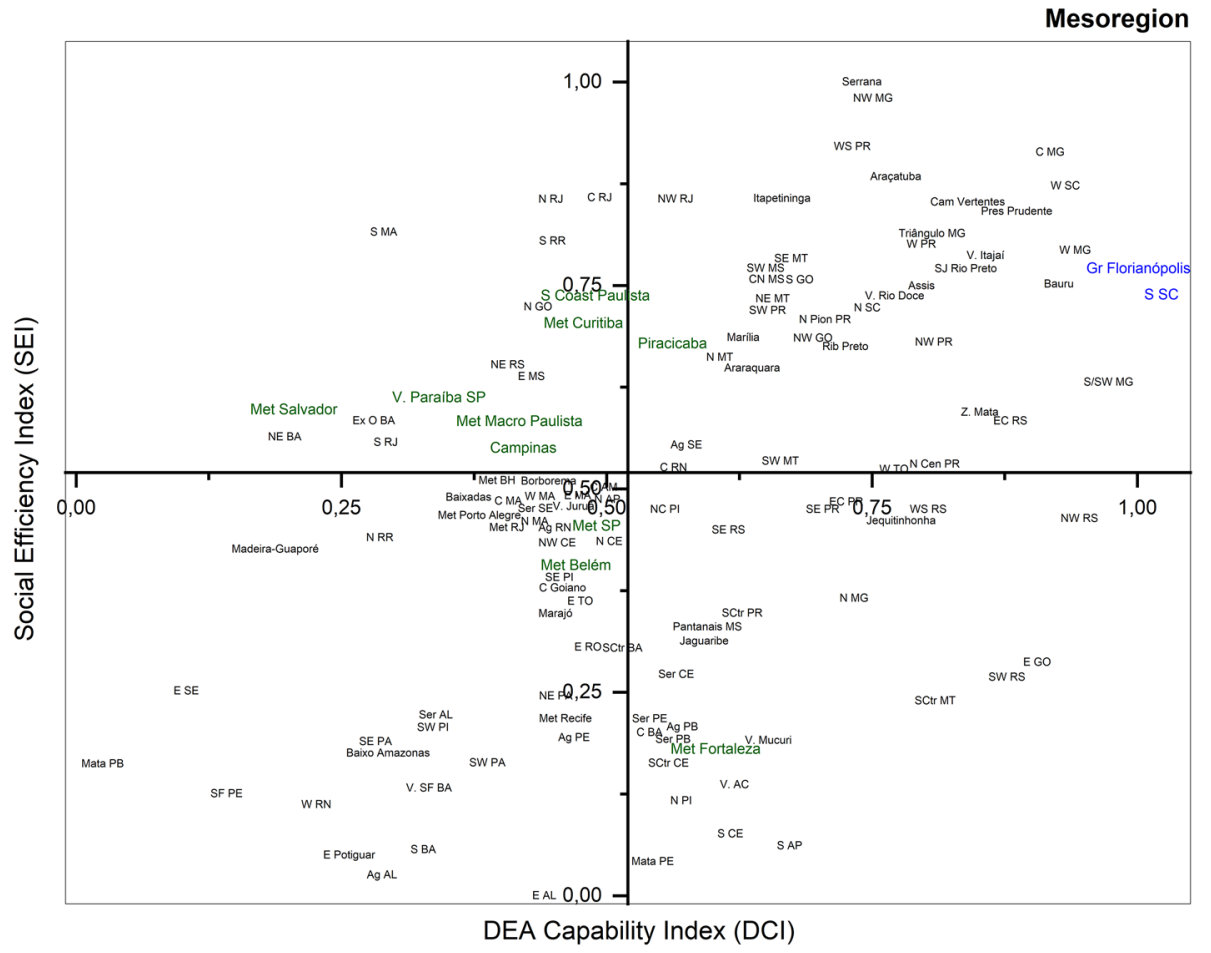

Fig. 1 Benchmarking the absolute (DCI) and relative (SEI) performance

In sum, CIASE measures the human development performance of regions by considering both their absolute and relative performance. This indicator can be used to rank regions according to the human development approach as well as social efficiency consideration. CIASE arguably presents a better understanding of social deprivation and social efficiency in the Brazilian territory. For example, CIASE reveals that the North and Northeast regions have relatively higher levels of social efficiency. This can be interesting information for an efficient allocation of Brazilian public investments.

\subsection{DFRP: Analyzing Social Deprivation and Financial Responsibility}

The Deprivation and Financial Responsibility based Prioritization Index (DFRP) can provide valuable information for national policymakers to merit poor regions that show a high level of social efficiency. A high DFRP indicates that this region presents a high level of social deprivation yet is also socially efficient. In other words, considering its very limited financial resources it does a relatively good job in promoting human development. The Top-5 DFRP regions are Northwest Rio-Grandense, East Goiano, South-west Rio-Grandense, Center-South Mato-Grossense, and Western Center Rio-Grandense. The results indicate that the national authorities might consider investing in these regions for the sake of efficient human development improvement. The Bottom-5 DFRP regions instead are South Maranhense, North Fluminense, Serrana, Center Fluminense, and Northwest Minas. 
Fig. 2 Ranking permutations

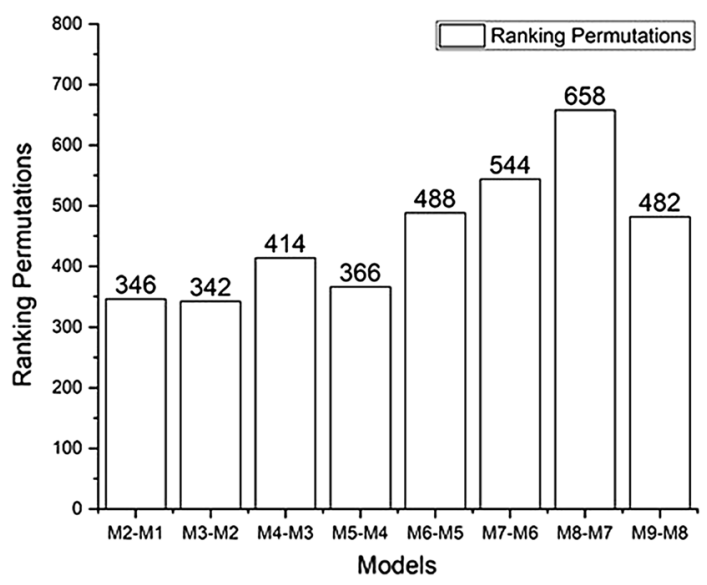

Having said this, our quantitative results also demand for subsequent in-depth case studies about the qualitative reasons for very high and low-ranking performances in the DRFP.

DFRP reveals that the Metropolitan Fortaleza (19th place), Metropolitan Recife (38th), and Metropolitan Belem (45th) should be prioritized to receive public investments over rich regions, such as Campinas (84th), Metropolitan Macro Paulista (92nd), Piracicaba (94th) and the South Coast Paulista (115th). This is an important finding because it suggests that authorities could discuss the redistribution of public expenditures towards less developed regions not only based on altruistic motives but also based on their merits in converting limited financial resources into human development. For example, while Metropolitan Belem receives R \$203 [U\$121] per capita, Campinas receives R \$567 [U\$340] per inhabitant in public expenditures of education and culture. In other words, authorities should give more credit to Metropolitan Belem because this region can face its social deprivation using public expenditures more efficiently.

The DFRP shows that some regions in the North and Northeast should be prioritized comparing to the South and Southeast of Brazil. In this sense, Brazilian authorities might reallocate public expenditures to develop poor social efficient regions. This reallocation would provide more homogeneity to the country as well as increase human development in all mesoregions.

Figure 4 represents maps of the performance of the Brazilian mesoregions in the six main indicators measured in this work. Dark green represents the regions with indicators close to one (maximum value), while light green represents the region with indicators close to zero (minimum value). The first map shows the distribution of the Capability Index with Equal Weights (CIEW). Thus, this map shows the human development performance, measured in a traditional way with equal weights. The second map shows the Deprivation Index (DI) which localizes regions facing more social deprivations from a DEA perspective. The third map represents the DEA Capability Index (DCI). This map shows which regions have better human development (dark green), according to the DEA perspective. The fourth map reveals the Social Efficiency Index (SEI) in Brazil. This map shows which regions are more efficient in converting their GDP and public expenditures in human development. The fifth map reveals the Capability Index Adjusted by Social Efficiency (CIASE). This map reveals a new interpretation of human development, combining absolute and relative perspectives. 


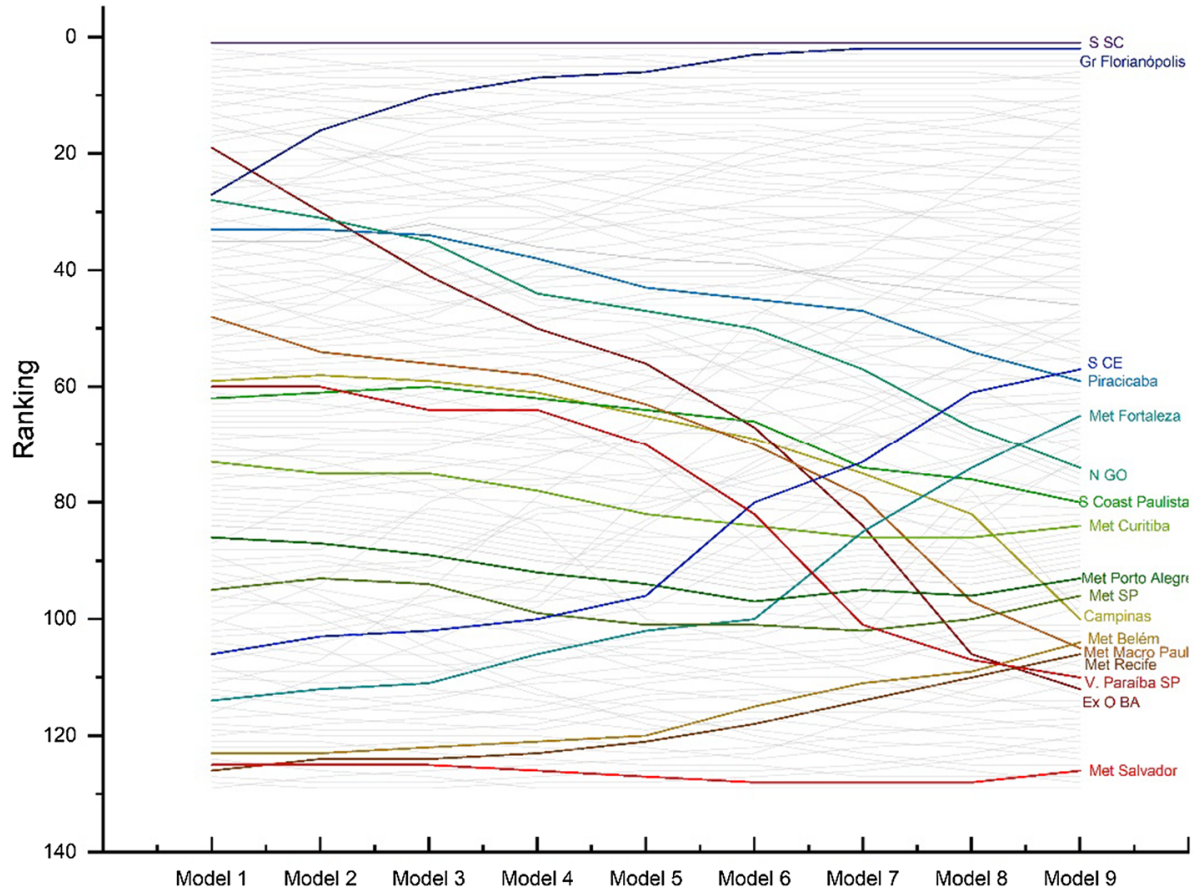

Fig. 3 Changing the ranking position of Brazilian mesoregions when the emphasis is put either on the absolute value (DCI) or social efficiency (SEI)

Finally, the sixth map illustrates the Deprivation and Financial Responsibility based Prioritization Index (DFRP).

\subsection{Cases for Discussion}

It is important to answer why some regions are more efficient than others. There are several reasons, such as the way that a region uses its money, the human capital to manage public funds, and the public policies to develop better living conditions, for example, to provide basic sanitation, health programs, and infrastructure.

Firstly, a region can spend its funds better and more efficiently in order to generate more access to public services. Regions such as the South Amapá, Metropolitan Belém, and Metropolitan Fortaleza are socially more efficient than Campinas, Piracicaba, and Metropolitan São Paulo because they can generate better human development indicators with less money. For example, Campinas spends R \$639 [U\$383] on health per inhabitant, yet only $70.08 \%$ of the population are vaccinated and have a life expectancy of 75.97 years. In contrast, the Metropolitan Belém spends R \$220 [U \$132] and presents $74.51 \%$ of the population vaccinated and a life expectancy of 72.5 years. So, it spends $289 \%$ less on health but has a $6.32 \%$ higher rate of vaccinated people.

Taking housing conditions as another example, the South Coast Paulista spends R \$291 [U\$174] per inhabitant in sanitation; however, only $81.82 \%$ of the households have access to piped water and sewage. In contrast, the Metropolitan Fortaleza spends R \$184 [U\$110] per inhabitant in sanitation, providing $89.15 \%$ of houses with piped water and sewage. In 

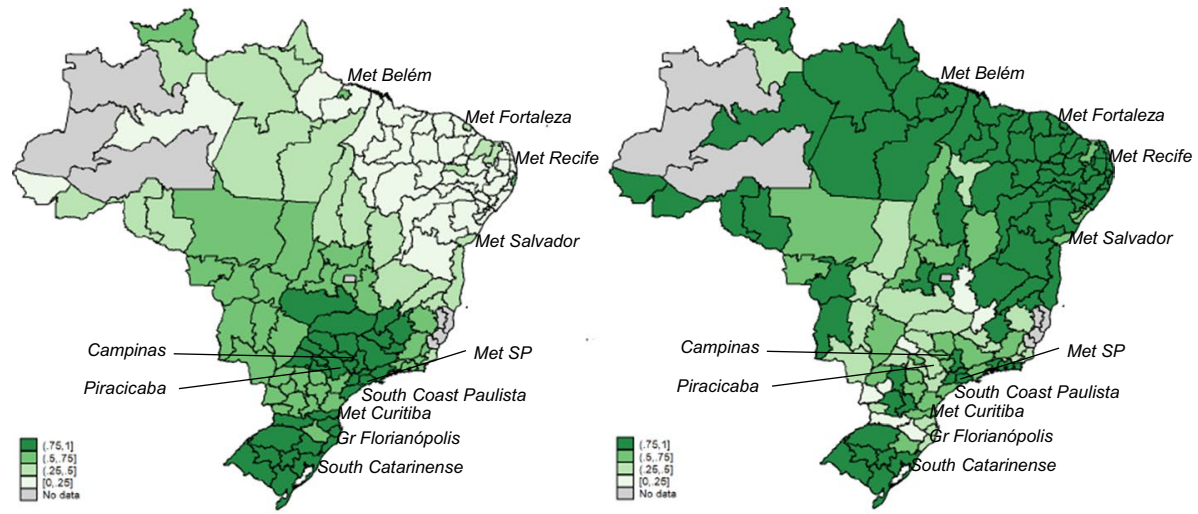

Capability Index with Equal Weights (CIEW)
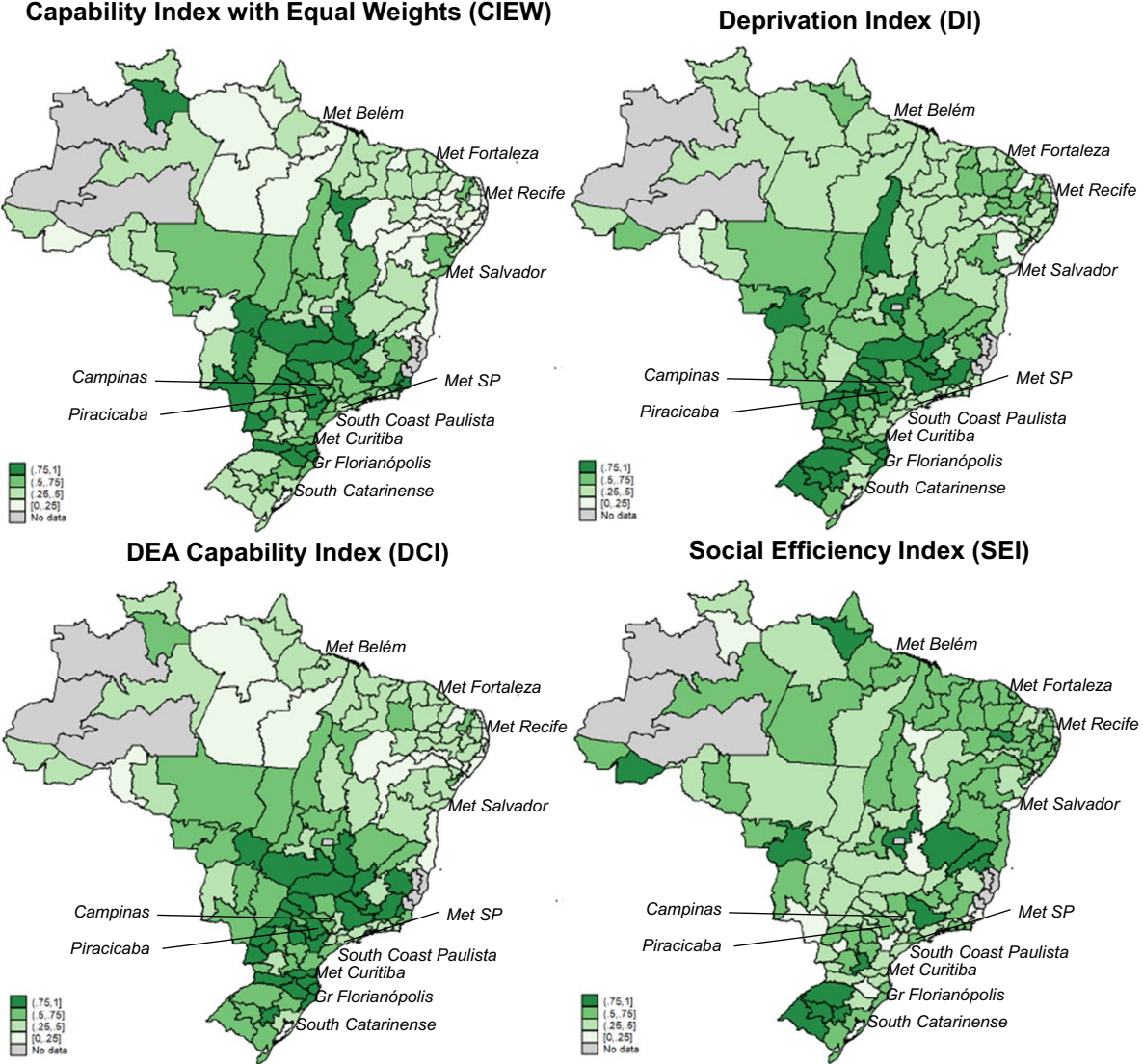

\section{Capability Index Adjusted by Social Efficiency (CIASE)}

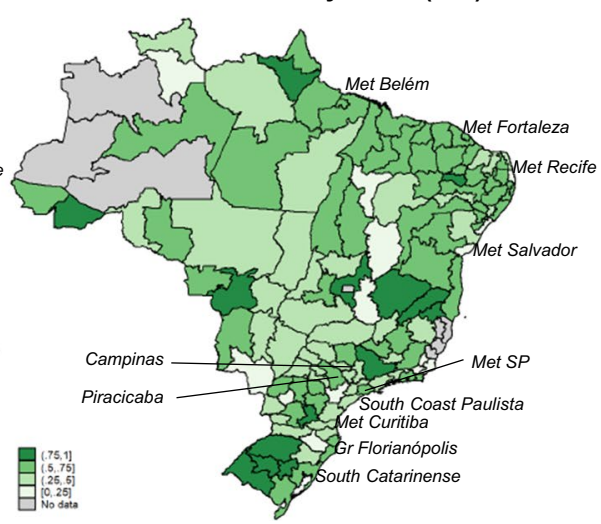

\section{Deprivation and Financial Responsibility} based Prioritization Index (DFRP)

Fig. 4 Socioeconomic performance of Brazilian mesoregions with respect to a absolute human development index, $\mathbf{b}$ social deprivation, $\mathbf{c}$ DEA absolute capability index, $\mathbf{d}$ social efficiency, $\mathbf{e}$ the capability index adjusted by social efficiency, and $\mathbf{f}$ the deprivation and financial responsibility based privatization index 
other words, Metropolitan Fortaleza spends $36.54 \%$ less than the South Coast Paulista and provides $8.96 \%$ more basic sanitation to its population. In this sense, SEI captures this efficiency of translating financial resources into human development.

Furthermore, SEI shows that GDP by itself is not enough to provide human development. We found that regions that have better fiscal management are also better at enhancing human development. Comparing the FIRJAN Fiscal Management Index ${ }^{2}$ (IFGF) with our indicators, we found a correlation between IFGF and CIASE (0.54), DCI (0.56), and SEI (0.35). This correlation suggests that better management of public resources is associated with higher levels of absolute, relative and combined aspects of the human development performance of regions. For example, the Fiscal Management Index of Metropoli$\tan$ Fortaleza (0.7120) is better than the IFGF of Campinas (0.608), Metropolitan Curitiba (0.6929), Piracicaba (0.617) and Metropolitan Macro Paulista (0.6173).

Finally, public policies can improve human development in different dimensions, and it is not only related to the region's GDP. For example, Metropolitan Macro Paulista, located in one of the most developed regions of Brazil, has a relative good ranking position in terms of absolute levels of human capabilities ( $\mathrm{DCI}=51$ st out of 129 regions). This region has universities and research institutes, national and multinational companies, hospitals with technological equipment, and a public transport system that is relatively better than in the rest of the country. The state of São Paulo is the richest in the country, with more public resources and GDP. However, when we analyze the generation of human development from GDP, the relative index (SEI) is only 0.351, which places this region on the position 108th of the national ranking. Similarly, Campinas and Piracicaba, in the São Paulo countryside are located near the financial center of Brazil (São Paulo city), have research institutes, universities, and companies in the technological field. According to the DCI, the Campinas region ranks 54th, yet it ranks only 105th place when analyzing the SEI efficiency of public spending and local GDP. Although the region Piracicaba ranks 40th in the DCI ranking, has important multinational companies (Griesse 2007) and significant public policies for professional qualification (Ferraz and Oliveira 2017), Piracicaba has a worse SEI performance (67th position). Furthermore, Metropolitan Curitiba, where there is an important automobile cluster (Cruz and Rolim 2010), does not have good position in SEI ranking (96th place), which is explained by previous studies on inequality (Lima and Bidarra 2019), housing (Monteiro 2015) and health (Aguilera et al. 2014).

In contrast, region Metropolitan Fortaleza, in the Northeast of the country, is ranked low in absolute terms (112th), and high in relative terms (59th). The main reasons for this are the public policies to improve educational attainment, to promote access to health in poor neighborhoods, and the percentage of illiteracy has declined because more people have attended school, which has also helped to the development of policies for health promotion (Ribeiro et al. 2018). In addition, Metropolitan Belém, in the North of Brazil, where many people are still living in rural areas composed of 39 islands (SIDRA 2019), has a Master Plan for Water Supply and Sanitation, supported by the Federal University of Pará and the Federal development policy (Magalhaes and Heller 2018).

The region Greater Florianopolis in the South of Brazil has a high absolute value and is ranked 22nd out of 129 mesoregions, however in terms of social efficiency it is ranked in the 2 nd position. Reasons for this are arguably its lowest per capital murder and robust

\footnotetext{
2 The IFGF is composed of five indicators (Own Revenue, Personnel Expenses, Investments, Liquidity and Debt Cost). This index varies between 0 and 1 , and the closer to 1 , the better the fiscal management of the municipality in the year under observation (FIRJAN, 2019).
} 
middle class (de Andrade et al. 2017), the infrastructure and economic diversification (Makowiecky and Carneiro Filho 2015; Yigitcanlar et al. 2017), the public universities and institutions to promote science and technology (Xavier 2010; Yigitcanlar et al. 2017), the knowledge-based economy and the innovation, scientific and technological promotion by local government (Esmaeilpoorarabi et al. 2016), the special vaccination program (Kupek and Tritany 2009) and, the favelas localization, which guarantees facilities in daycare centers, schools and hospitals (Yigitcanlar et al. 2017). Moreover, Mata Moraes et al. (2018) show that multidimensional poverty has declined in the state of Santa Catarina from $26.66 \%$ in 2000 to $15.07 \%$ in 2010 . All coefficients and rankings can be found in "Appendix II". Nonetheless, our literature review illustrate that different regions of Brazil face heterogeneous problems. Regressions are able to identify significant trends, but DEA methods and subsequently case studies also allow for identification of the heterogeneous problems and strengths that regions face in terms of human development and social efficiency.

Finally, we observe how complex is the relation between absolute human development and social efficiency in Brazil. While regions in the North and Northeast are still facing social deprivation, regions in the South and Southeast present better absolute indicators. However, taking into account social efficiency, authorities should give more credit to poor, but relatively efficient regions. In sum, DEA informed indicators might help in the complex task of allocating public expenditures more efficiently. In particular, they may help to increase human development in poor regions spending public money more efficiently.

\section{Conclusions}

In this study, we evaluated how absolute and relative indicators can be used to reveal the human development and social efficiency performance of regions. Applying methods from Data Envelopment Analysis, we found many changes in ranking position according to the emphasis of the indicators on absolute or relative dimensions of human development. Several regions with good absolute indicators showed worse performance in the relative ranking. On the other hand, some regions with worse social deprivation were socially efficient.

To our best knowledge, there are not yet any DEA inspired indicators that combine absolute and relative indicators within composite indicators. To fill this gap, we combine these two indicators and create the Capability Index Adjusted by Social Efficiency (CIASE) and the Deprivation and Financial Responsibility Based Prioritization Index (DFRP. These indicators are especially valuable in countries with heterogeneous regions like Brazil. CIASE allows for a new interpretation of human development achievements in Brazil, taking both absolute levels of deprivation and capabilities into account, as well as considering financial responsibility. In addition, CIASE deals with other types of research problems whenever there is a significant difference between inputs and outputs (e.g. to compare public investments among countries or to analyze sustainability among regions or countries).

In order to identify which regions should receive higher public investments for human development, we created the Deprivation and Financial Responsibility Based Prioritization Index (DFRP). This indicator takes into account the regions with the most significant social deprivation and at the same time relative high levels of financial responsibility. In this way, policymakers can use the DFRP to reallocate public resources in order to generate human development by spending public money more efficiently. We also presented some cases to discuss different strategies in Brazil's mesoregions. However, authorities must 
interpret the CIASE and DFRP indicators carefully and evaluate the rankings accompanied by case studies.

There are several limitations that must be mentioned. First, we did not consider the temporal evolution of human development. Second, our analysis is concentrated on global indicators. Third, we did not discuss which weights should and could be assigned to each social dimension. We consider that future studies can analyze the evolution of human development in Brazil over time, measure specific indices for each dimension (education, health, basic sanitation, employment, and institutions), discuss different weights of each dimension in a global index (e.g. - health and education are more important than sanitation or institutions), and proceed with advanced econometric studies to understand the causal linkages between the inputs and outputs better. Finally, a more in-depth discussion of the ethical importance of social efficiency and its ability to sustain social policies is necessary. One relevant question for further research is to what extent public investment should focus on absolute deprivations, social efficiency, or a combination of both. Policy measures need to address socially inefficiencies and invest in regions with high levels of human deprivation but should probably also merit regions that do an efficient job. The precise resource allocation and ethical priority setting, though, requires further discussion and seems to be a promising path for future research on human development and social efficiency with relevance for public investment decisions.

Despite the limitations outlined above, our work reveals the need to simultaneously analyze social deprivation, social efficiency and financial responsibility in developing regions. In this regard, our study points to the possibilities of constructing new indicators that combine information on absolute levels of human development and the financial responsibility of regions. Our indicators point to the need for considering aspects of financial responsibility when (re)allocating GDP and public expenditures for human development improvements. Thus, CIASE and DFRP help to identify and promote the financial responsibility of regions in promoting human development.

Acknowledgments Open Access funding provided by Projekt DEAL. Diogo Ferraz would like to express his gratitude for the financial support of Coordenação de Aperfeiçoamento de Pessoal de Nível Superior (CAPES) (Process No. 88887.161388/2017-00), the Lions-Club-Förderpreis (Stuttgart/Germany) and the Friedrich-Naumann-Stiftung für die Freiheit. Dominik Hartmann would like to express his gratitude for the financial support of FAPESP (Processo 2017/19842-2) as Visiting Scholar at the University of São Paulo.

Open Access This article is licensed under a Creative Commons Attribution 4.0 International License, which permits use, sharing, adaptation, distribution and reproduction in any medium or format, as long as you give appropriate credit to the original author(s) and the source, provide a link to the Creative Commons licence, and indicate if changes were made. The images or other third party material in this article are included in the article's Creative Commons licence, unless indicated otherwise in a credit line to the material. If material is not included in the article's Creative Commons licence and your intended use is not permitted by statutory regulation or exceeds the permitted use, you will need to obtain permission directly from the copyright holder. To view a copy of this licence, visit http://creativecommons.org/licenses/by/4.0/. 


\section{Appendix I: Econometric Validation}

Linear regressions were estimated between the inputs and each of the outputs. We proceeded with Cobb-Douglas functions adapted to the research problem (see Expression 2).

$$
\begin{aligned}
\operatorname{lny}_{\mathrm{it}}^{\text {social variable }}= & \beta_{0}+\beta_{1} \operatorname{lnUrbanPop}_{i t}+\beta_{2} \ln E A P_{i t}+\beta_{3} \ln G D P_{i t}+\beta_{4} \ln E_{\text {Exp_Educ_Cult }} \\
& +\beta_{5} \ln \text { Exp_Housing }_{i t}+\beta_{6} \ln E x p \_H e a l t h \_S a n_{i t}+\varepsilon_{i t}(3)
\end{aligned}
$$

where: $\ln y_{\text {it }}^{\text {social variable }}$ is one of the 14 variables of human development; $\beta_{0}$ is the intercept; $\beta_{1} \ln U$ rbanPop is the natural logarithm of the urban population in each region; $\beta_{2} \ln E A P$ is the natural logarithm of the economically active population; $\beta_{3} \ln G D P$ is the natural logarithm of the gross domestic product; $\beta_{4} \ln E x p \_E d u c_{-} C$ Cult is the natural logarithm of the public expenditure in education and culture; $\beta_{5} \ln$ Exp_Housing is the natural logarithm of the public expenditure in habitation and; $\beta_{6} \ln E x p \_H e a l t h \_S a n$ is the natural logarithm of health and sanitation.

We used a log-log regression to interpret the parameters as elasticities (Greene 2011). We also applied the following tests: the Hausman test to define Fixed Effects (FE) or Random Effects (RE) models (Hausman 1978; Holland and Xavier 2005); the Breusch-Pagan to check heteroskedasticity in our regression model (Greene 2011); and the Variance Inflation Factor (VIF), which must be less than 10, so that there is no multicollinearity (Stine 1995).

For the education dimension, we found that GDP and expenditures in education and culture have a positive impact on the number of literate people and the number of daycare centers. For the housing conditions, GDP and expenditures in housing improve public services (electricity, sewage, and garbage collection), as well as decrease the housing deficit.

For the health dimension, GDP and public expenditures in health increase life expectancy and the number of vaccinated people. On the other hand, investing in health decreases the child mortality rate. Furthermore, the economic dimension shows that GDP and expenditures in education increase employment. In contrast, they reduce income inequality (Gini index and the number of extremely poor people).

For institutions, our findings suggest that democracy is positively impacted by GDP and expenditures in education. Our analysis also showed that housing spending reduces the homicide rate, as long as investing in this type of infrastructure improves living conditions in deprived areas and slums (favelas), where the highest number of homicides occur over the year (Ceccato 2005).

See Table 5. 


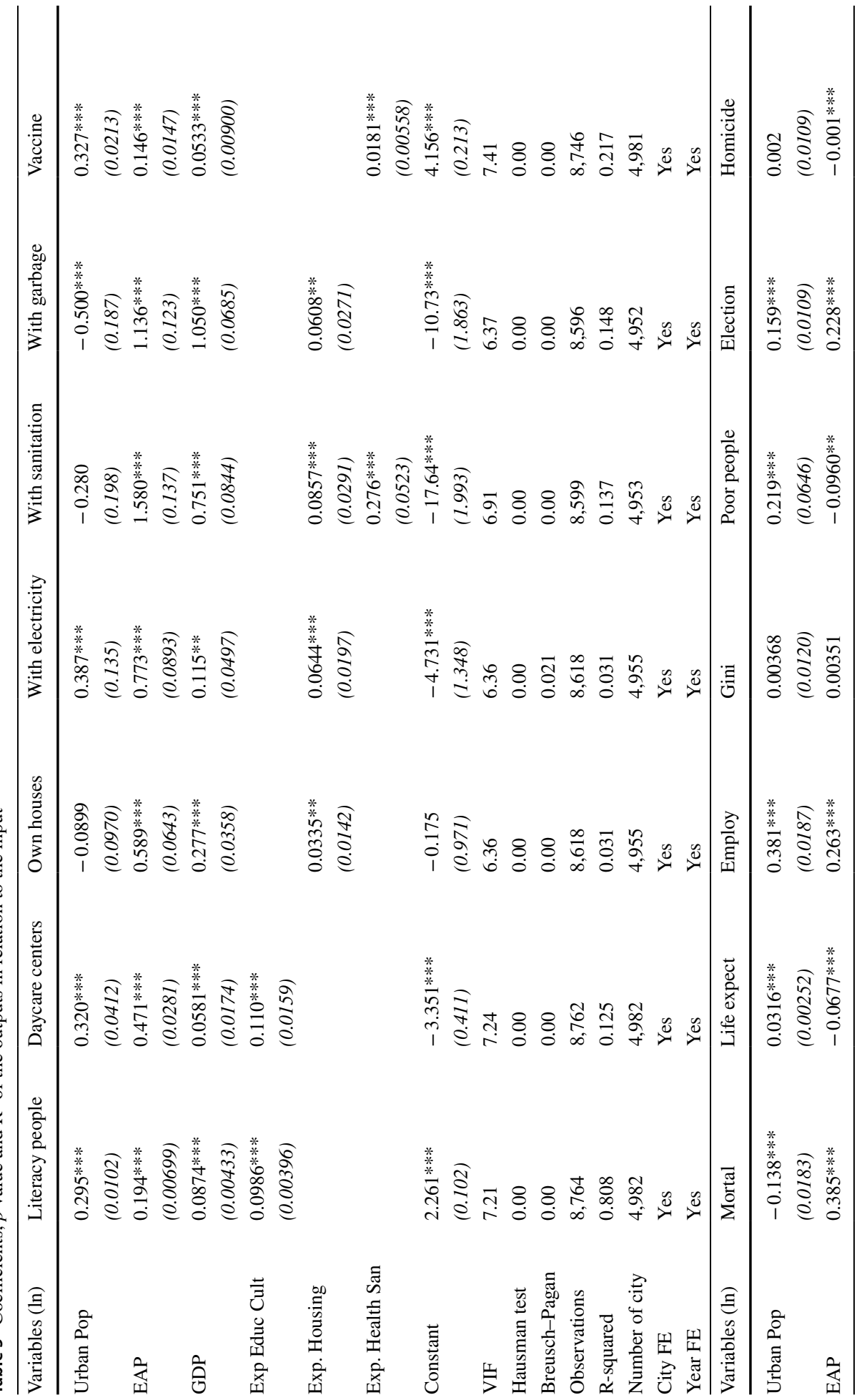




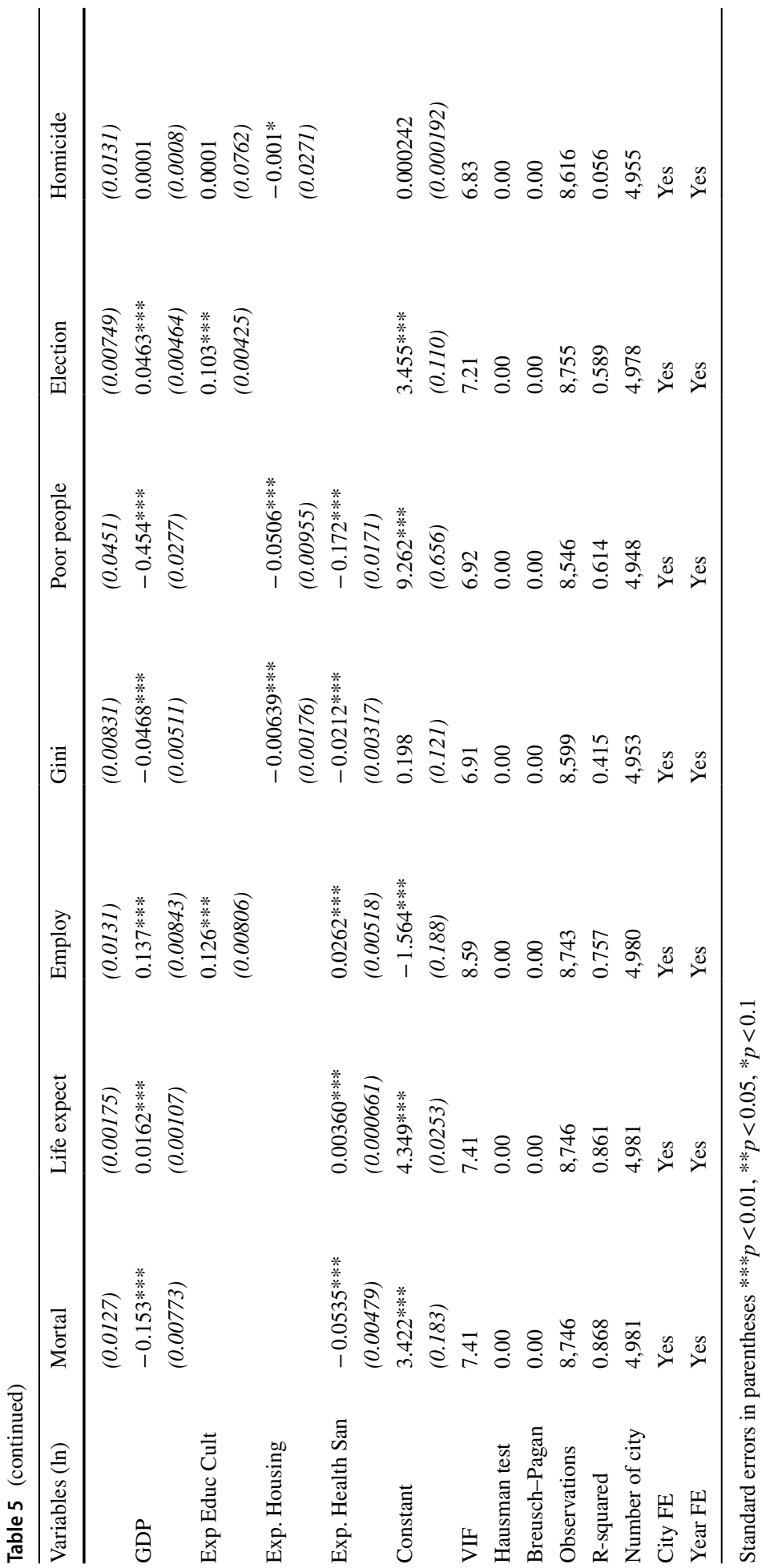




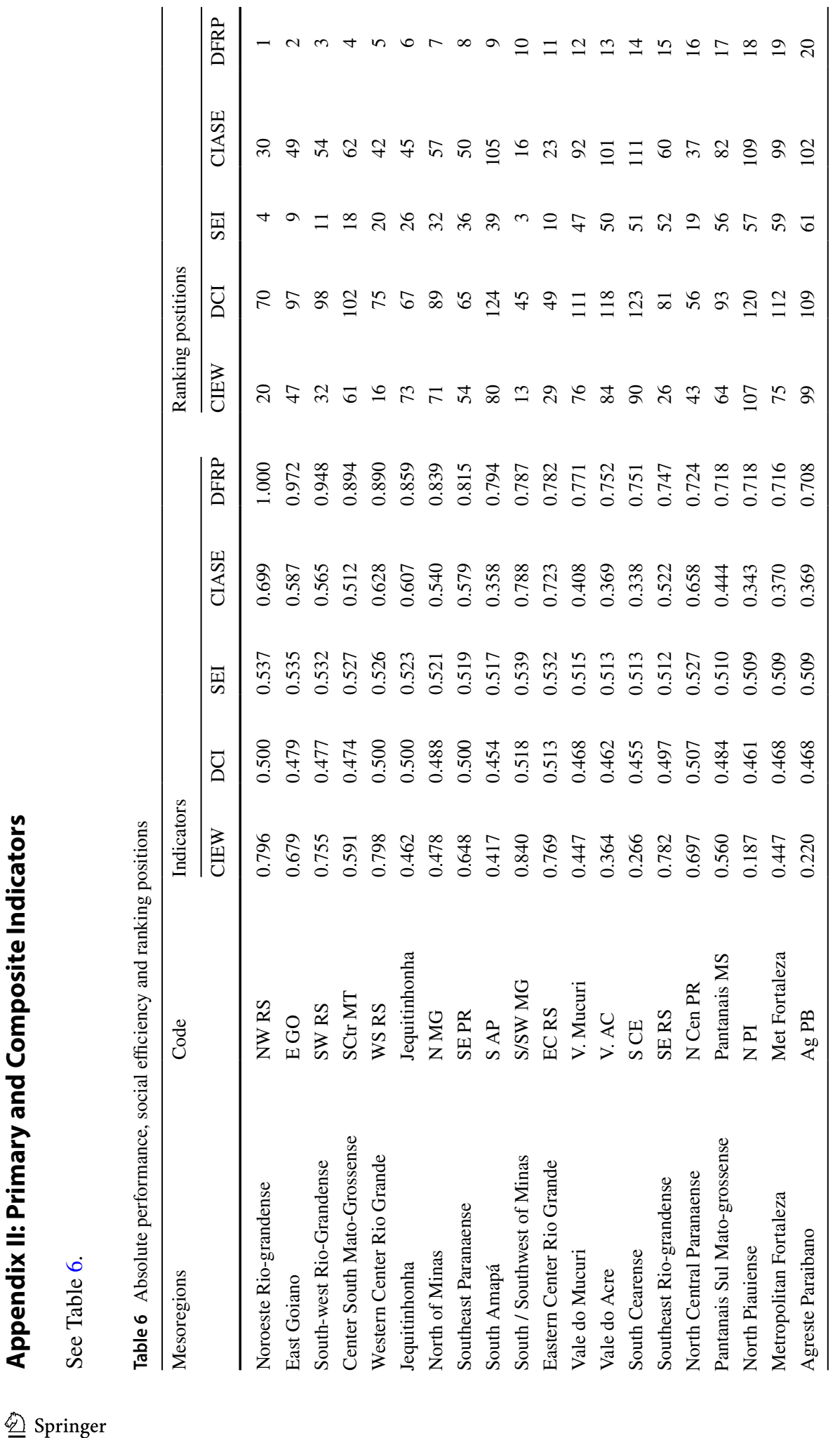




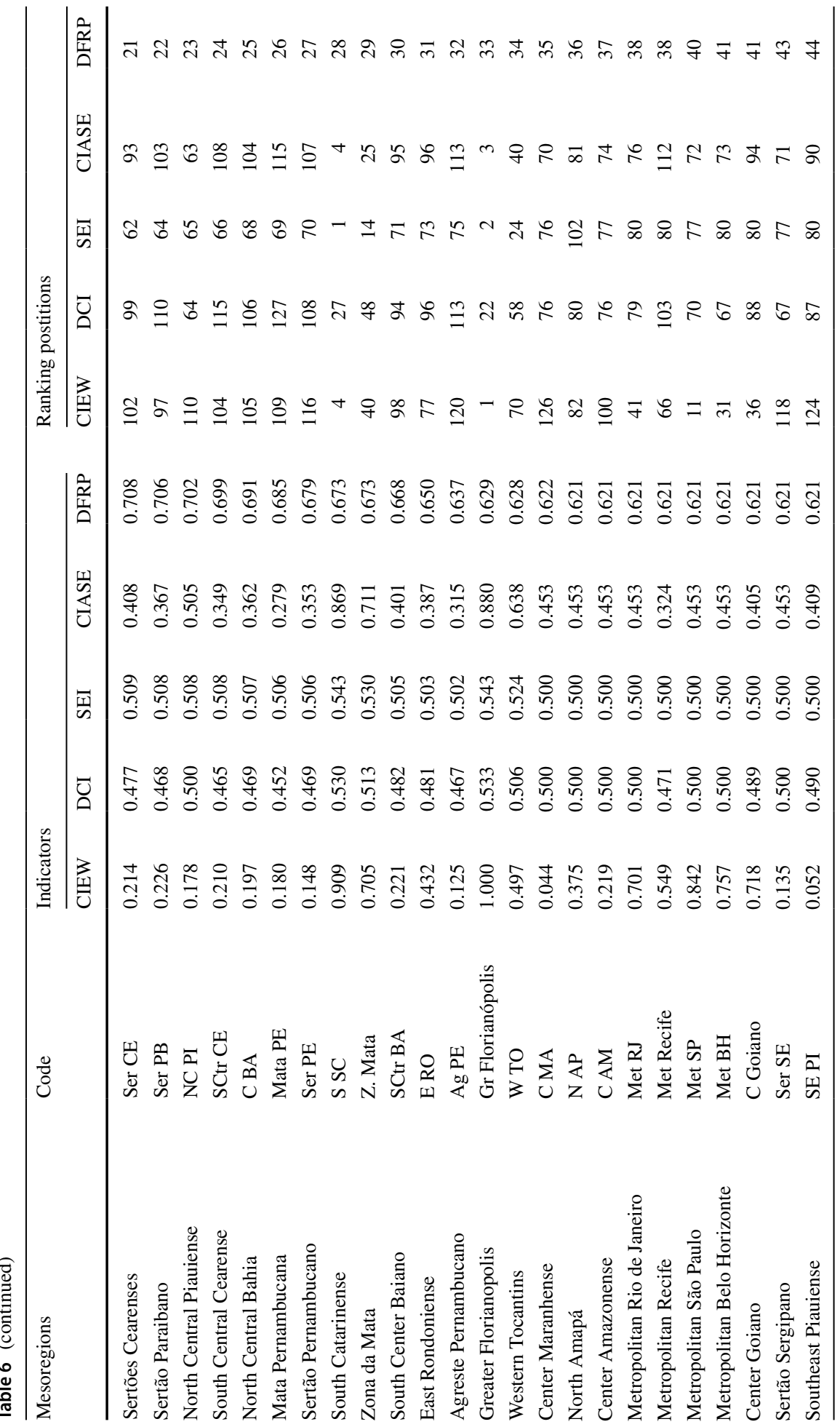




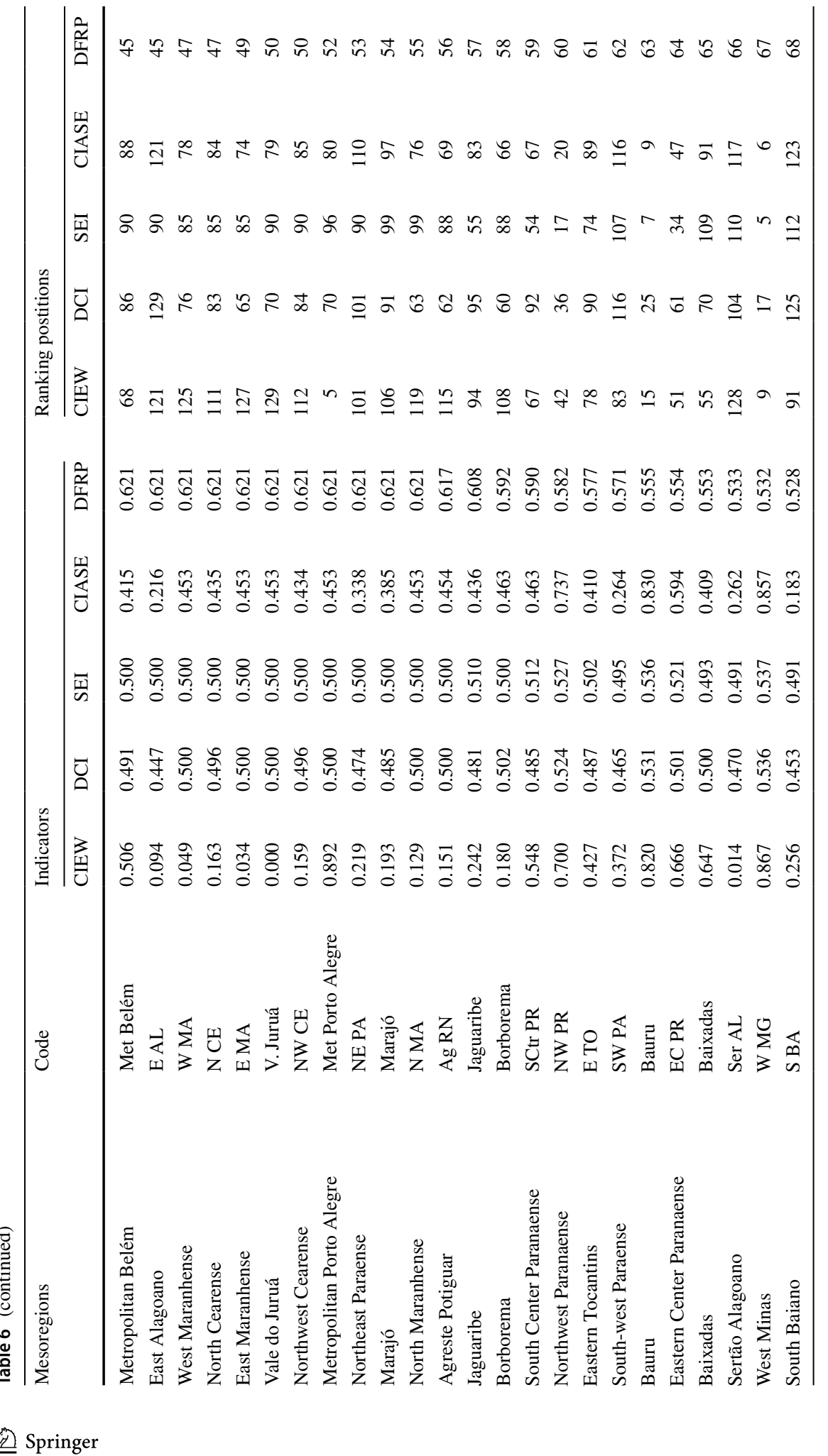




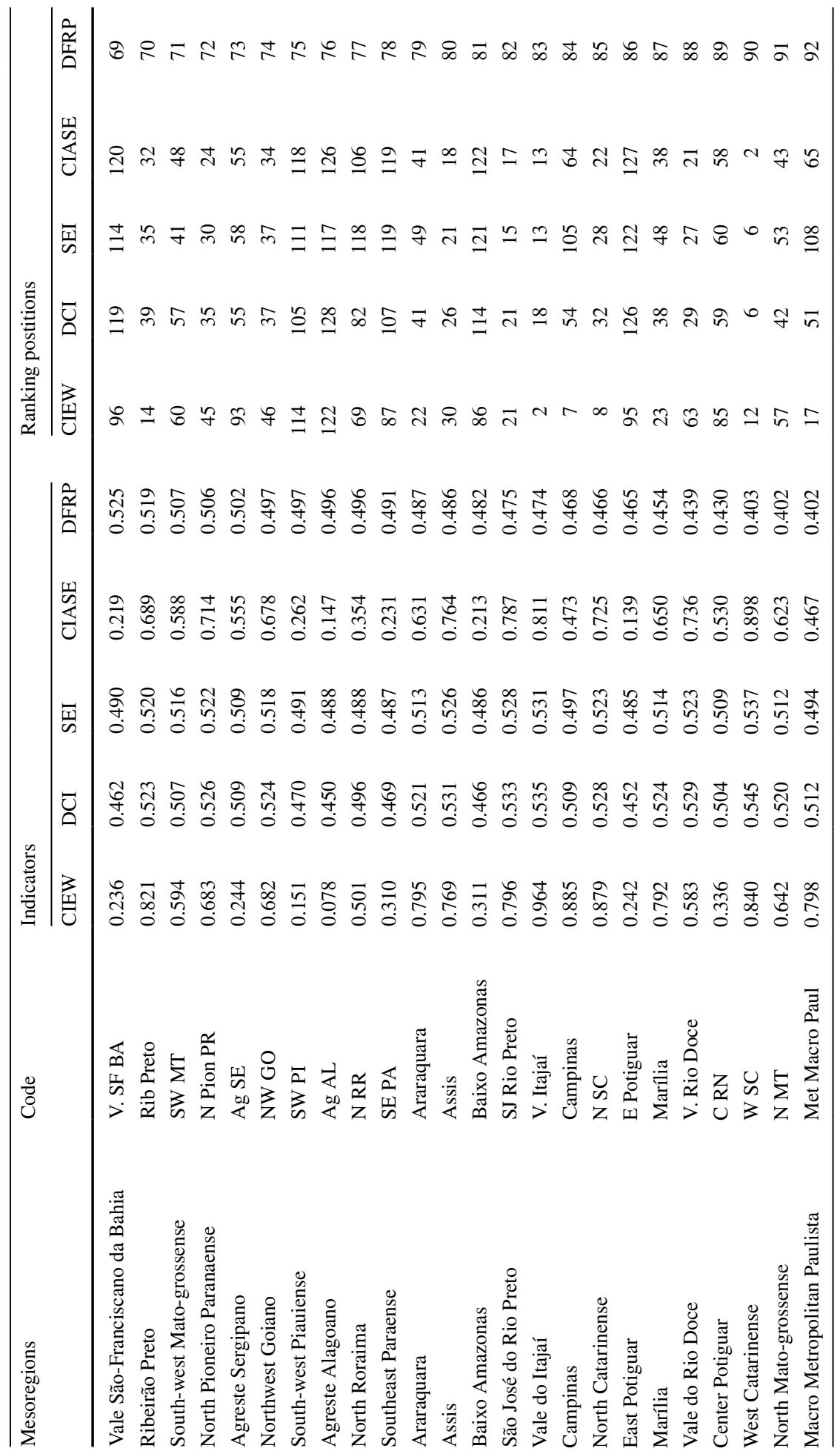




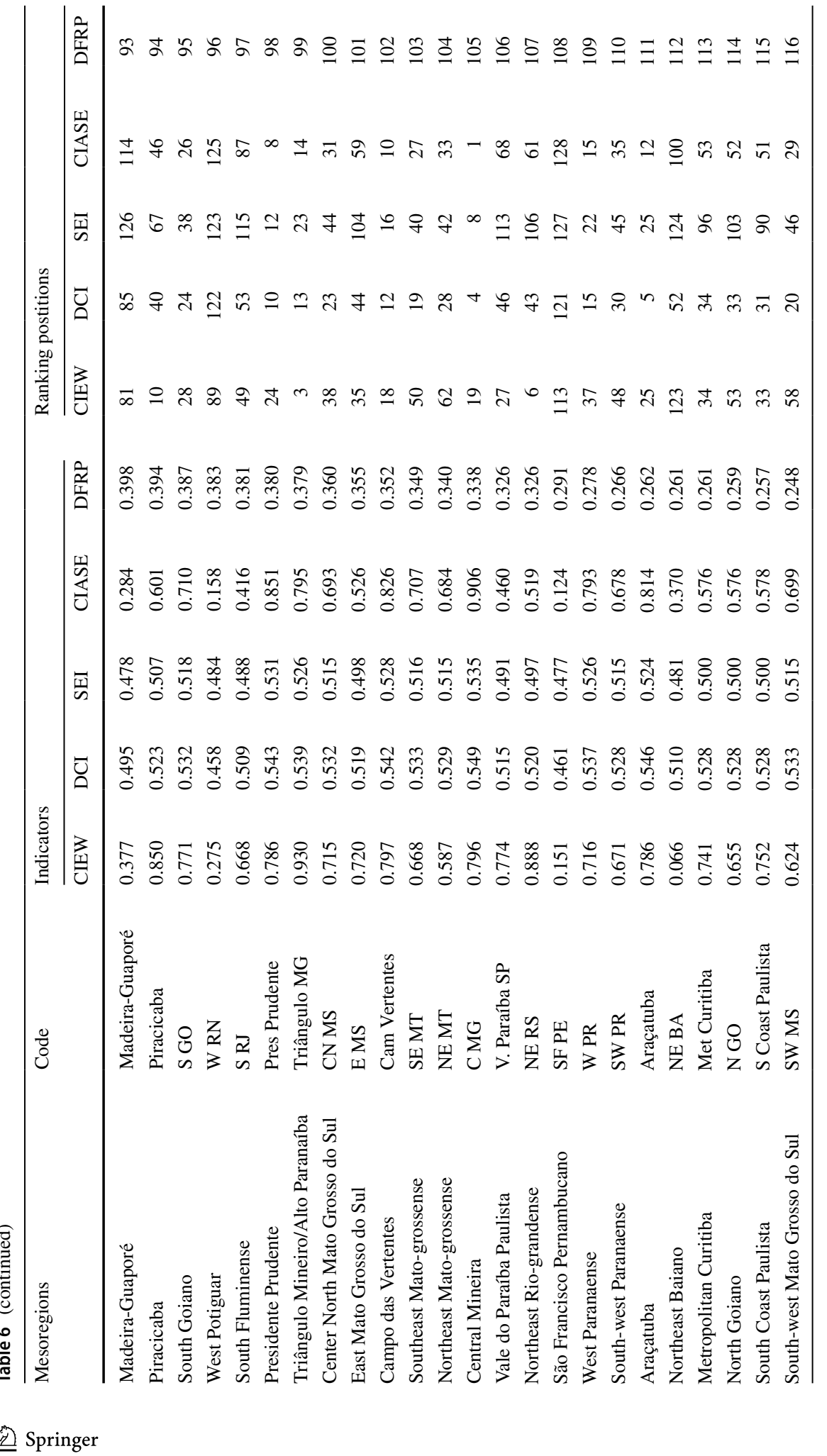




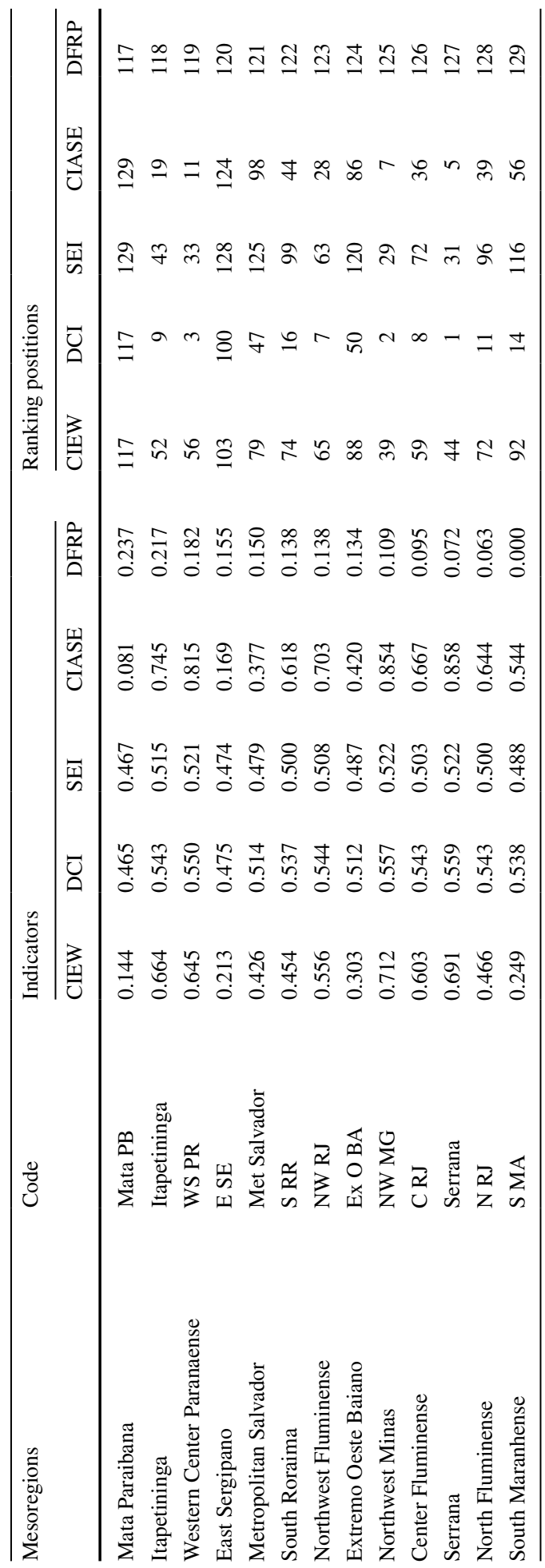




\section{References}

Adler, N., Yazhemsky, E., \& Tarverdyan, R. (2010). A framework to measure the relative socio-economic performance of developing countries. Socio-Economic Planning Sciences, 44(2), 73-88.

Aguilera, S. L. V. U., França, B. H. S., Moysés, S. T., \& Moysés, S. J. (2014). Intermunicipal inequities in access and use of secondary health services in the metropolitan area of Curitiba. Revista Brasileira de Epidemiologia, 17, 654-667.

Alkire, S., \& Foster, J. (2011). Counting and multidimensional poverty measurement. Journal of public economics, 95(7-8), 476-487.

Anand, S., \& Sen, A. (1994). Human development index: Methodology and measurement. New York: UNDP.

Anand, S., \& Sen, A. (2000). Human development and economic sustainability. World development, 28(12), 2029-2049.

Andrett, M. C. S., Lunkes, R. J., da Rosa, F. S., \& Baccin Brizolla, M. M. (2018). Public expense efficiencies with health in Brazil: Study about Brazilian state performances. Revista de Gestao em Sistemas de Saude-RGSS, 7(2), 114-128.

Angulo-Meza, L., \& Lins, M. P. E. (2002). Review of methods for increasing discrimination in data envelopment analysis. Annals of Operations Research, 116(1-4), 225-242. https://doi.org/10.1023/A:10213 40616758.

Antonelli, M. A., \& de Bonis, V. (2019). The efficiency of social public expenditure in European countries: A two-stage analysis. Applied Economics, 51(1), 47-60.

Ararat, L. O. (2013). Corruption and democracy in Brazil: The struggle for accountability. Journal of Comparative Policy Analysis: Research and Practice, 15(2), 199-202. https://doi.org/10.1080/13876 988.2013.787191.

Araujo, C. A. S., Wanke, P., \& Siqueirda, M. M. (2018). A performance analysis of Brazilian public health: TOPSIS and neural networks application. International Journal of Productivity and Performance Management, 67(9), 1526-1549. https://doi.org/10.1108/IJPPM-11-2017-0319.

Armijo, L. E., \& Rhodes, S. D. (2017). Explaining infrastructure underperformance in Brazil: Cash, political institutions, corruption, and policy Gestalts. Policy Studies, 38(3), 231-247. https://doi. org/10.1080/01442872.2017.1290227.

Azeem Qureshi, M. (2009). Human development, public expenditure and economic growth: A system dynamics approach. International Journal of Social Economics, 36(1/2), 93-104.

Ballet, J., Dubois, J. L., \& Mahieu, F. R. (2007). Responsibility for each other's freedom: Agency as the source of collective capability. Journal of Human Development, 8(2), 185-201.

Banker, R. D., Conrad, R. F., \& Strauss, R. P. (1986). A comparative application of data envelopment analysis and translog methods: An illustrative study of hospital production. Management Science, 32, $30-44$.

Bernini, C., Guizzardi, A., \& Angelini, G. (2013). DEA-like model and common weights approach for the construction of a subjective community well-being indicator. Social Indicators Research, 114(2), 405-424.

Beuren, M. M., Andriotti, R., Vieira, G. B. B., Ribeiro, J. L. D., \& Neto, F. J. K. (2018). On measuring the efficiency of Brazilian ports and their management models. Maritime Economics \& Logistics, 20(1), 149-168.

Bhagwati, J. (1993). India in transition. Freeing the economy. New York: Oxford University Press.

Bilbao-Ubillos, J. (2013a). Another approach to measuring human development: The composite dynamic Human Development Index. Social Indicators Research, 111(2), 473-484.

Bilbao-Ubillos, J. (2013b). The limits of Human Development Index: The complementary role of economic and social cohesion, development strategies and sustainability. Sustainable Development, 21(6), $400-412$.

Blancard, S., \& Hoarau, J.-F. (2013). A new sustainable human development indicator for small island developing states: A reappraisal from data envelopment analysis. Economic Modelling, 30, 623-635.

Boncinelli, F., \& Casini, L. (2014). A comparison of the well-being of agricultural and non agricultural households using a multicriterial approach. Social Indicators Research, 119(1), 183-195.

Bougnol, M. L., \& Dulá, J. H. (2006). Validating DEA as a ranking tool: An application of DEA to assess performance in higher education. Annals of Operations Research, 145(1), 339-365.

Brito, A., Foguel, M., \& Kerstenetzky, C. (2017). The contribution of minimum wage valorization policy to the decline in household income inequality in Brazil: A decomposition approach. Journal of Post Keynesian Economics, 40(4), 540-575. 
Campos, R. B. A., \& Guilhoto, J. J. (2017). The socioeconomic impact of low-income housing programs: An interregional input-output model for the state of Sao Paulo and the rest of Brazil. Habitat International, 65, 59-69.

Carvalho, M., \& Syguiy, T. (2015). Efficiency and effectiveness analysis of public transport of Brazilian cities. Journal of Transport Literature, 9(3), 40-44.

Ceccato, V. (2005). Homicide in Sao Paulo, Brazil: Assessing spatial-temporal and weather variations. Journal of Environmental Psychology, 25(3), 307-321.

Central Bank of Brazil. (2019). Time series management system—v2.1. Brasília. https://www.bcb.gov.br/ en\#!/home. Retrieved February, 012019.

Cervantes, N., \& Radge, Z. (2018). Weber's bureaucratic model in Brazil: The corruption of ideas as obstacles to the implementation of public policies. Geoforum.

Chaaban, J. M. (2009). Measuring youth development: A nonparametric cross-country 'youth welfare index'. Social Indicators Research, 93(2), 351-358.

Chaaban, J., Irani, A., \& Khoury, A. (2016). The composite global well-being index (CGWBI): A new multi-dimensional measure of human development. Social Indicators Research, 129(1), 465-487.

Charnes, A., Cooper, W. W., \& Rhodes, E. (1978). Measuring the efficiency of decision making units. European Journal of Operational Research, 2(6), 429-444.

Chowdhury, S., \& Squire, L. (2006). Setting weights for aggregate indices: An application to the commitment to development index and human development index. Journal of Development Studies, 42(5), $761-771$.

Coelho, V. S. (2018). Reducing health inequalities in Brazil's universal health-care system: Accountability politics in São Paulo. IDSBulletin, 49(2)

Cook, W. D., \& Zhu, J. (Eds.). (2014). Data envelopment analysis: A handbook of modeling internal structure and network, 208. Berlin: Springer.

Cooper, W. W., Seiford, L. M., \& Tone, K. (2006). Introduction to data envelopment analysis and its uses: with DEA-solver software and references. Berlin: Springer.

Costa, G. O. T., Machado, A. F., \& Amaral, P. V. (2018). Vulnerability to poverty in Brazilian municipalities in 2000 and 2010: A multidimensional approach. EconomiA, 19(1), 132-148.

Cruz, M. J. V., \& Camargo Rolim, C. F. (2010). The Brazilian automotive industry in the BRICs context: The case of the Metropolitan Region of Curitiba. Cambridge Journal of Regions, Economy and Society, 3(3), 319-334.

Davies, A., \& Quinlivan, G. (2006). A panel data analysis of the impact of trade on human development. Journal of Socio-Economics, 35(5), 868-876.

de Andrade, J. B. S. O. (2017). Reprint of: The adoption of strategies for sustainable cities: A comparative study between Newcastle and Florianópolis focused on urban mobility. Journal of cleaner production, 163, S209-S222.

de Castro Camioto, F., Mariano, E. B., \& do Nascimento Rebelatto, D. A. (2014). Efficiency in Brazil's industrial sectors in terms of energy and sustainable development. Environmental Science \& Policy, 37, 50-60.

de Sousa, M. D. C. S., \& Ramos, F. S. (2017). Technical efficiency and returns to scale in local public spending in the presence of heterogeneous data: The Brazilian case. In Revival: Structure and Structural Change in the Brazilian Economy, (2001) (pp. 195-218). Routledge.

Despotis, D. K. (2005a). A reassessment of the human development index via data envelopment analysis. Journal of the Operational Research Society, 56(8), 969-980.

Despotis, D. K. (2005b). Measuring human development via data envelopment analysis: The case of Asia and the Pacific. Omega, 33(5), 385-390.

Domínguez-Serrano, M., \& Blancas, F. J. (2011). A gender wellbeing composite indicator: The best-worst global evaluation approach. Social Indicators Research, 102(3), 477-496.

Doraid, M. (1997). Analytical tools for human development. New York: PNUD.

Dossel, D. P., \& Gounder, R. (1994). Theory and measurement of living levels: Some empirical results for the Human Development Index. Journal of International Development, 6, 415-435.

Dreze, J., \& Sen, A. (1990). Hunger and public action. Oxford: Clarendon Press.

Dutu, R., \& Sicari, P. (2016). Public spending efficiency in the OECD: Benchmarking health care, education and general administration. OECD Economic Department Working Papers, (1278), 0_1.

Esmaeilpoorarabi, N., Yigitcanlar, T., \& Guaralda, M. (2016). Place quality and urban competitiveness symbiosis? A position paper. International Journal of Knowledge-Based Development, 7, 4-21.

Ferraz, D., Moralles, H. F., Campoli, J. S., Oliveira, F. C. R. D., \& Rebelatto, D. A. D. N. (2018). Economic complexity and human development: DEA performance measurement in Asia and Latin America. Gestão \& Produção, 25(4), 839-853. 
Ferraz, D., \& de Oliveira, F. C. R. (2017). Impact of the National Professional Qualification Program (PNQ) on Income: An Econometric Analysis in Piracicaba/SP-Brazil. Pesquisa \& Debate. Revista do Programa de Estudos Pós-Graduados em Economia Política, 28(2(52)), 105-123.

Frericks, P., \& Höppner, J. (2019). Self-responsibility readdressed: Shifts in financial responsibility for social security between the public realm, the individual, and the family in Europe. American Behavioral Scientist, 63(1), 65-84.

FIRJAN. (2010). Federação das Indústrias do Estado do Rio de Janeiro: IFDM 2010. https://www.firjan.org. br. Retrieved January 25, 2010.

Fukuda-Parr, S., Lawson-Remer, T., \& Randolph, S. (2010). An index of economic and social rights fulfillment: Concept and methodology. Journal of Human Rights, 8(3), 195-221.

Golany, B., \& Roll, Y. (1989). An application procedure for DEA. Omega, 17(3), 237-250.

González, E., Cárcaba, A., \& Ventura, J. (2011). The importance of the geographic level of analysis in the assessment of the quality of life: The case of Spain. Social Indicators Research, 102(2), 209-228.

Gormely, P. J. (1995). The human development index in 1994: Impact of income on country rank. Journal of Economic and Social Measurement, 21, 253-267.

Greene WH (2011) Econometric Analysis. New York: Prentice Hall.

Griesse, M. A. (2007). Caterpillar's interactions with Piracicaba, Brazil: A community-based analysis of CSR. Journal of business ethics, 73(1), 39-51.

Griffin, K., \& Knight, J. (1980s). Human development in the 1980s and beyond. Journal of Development Planning, 19, 9-40.

Grimm, M., Harttgen, K., Misselhorn, M., \& Klasen, S. (2008). A human development index by income groups. World Development, 36(12), 2527-2546.

Guardiola, J., \& Picazo-Tadeo, A. J. (2014). Building weighted-domain composite indices of life satisfaction with data envelopment analysis. Social Indicators Research, 117(1), 257-274.

Haddad, E. A. (2018). Regional inequality and structural changes: Lessons from the Brazilian experience. London: Routledge.

Hall, A. (2006). From Fome Zero to Bolsa Família: Social policies and poverty alleviation under Lula. Journal of Latin American Studies, 38(4), 689-709.

Haq, M. (1973). System is to blame for the 22 wealthy families. The London Times, 22.

Hartmann, D. (2014). Economic complexity and human development: How economic diversification and social networks affect human agency and welfare. London: Routledge.

Hartmann, D., Jara Figueroa, C., Kaltenberg, M., \& Gala, P. (2019). Mapping Stratification: The industryoccupation space reveals the network structure of inequality (June 5, 2019). Available at SSRN: https ://papers.ssrn.com/sol3/papers.cfm?abstract_id=3399239

Hashimoto, A., \& Ishikawa, H. (1993). Using DEA to evaluate the state of society as measured by multiple social indicators. Socio-Economic Planning Sciences, 27(4), 257-268.

Hausman, J. A. (1978). Specification Tests in Econometrics. Econometrica, 46(6), 1251-1271. https://doi. org/10.2307/1913827.

Herrero, C., Martínez, R., \& Villar, A. (2010). Multidimensional social evaluation. An application to the measurement of human development. Review of Income and Wealth, 56, 483-497.

Hicks, D. A. (1997). The inequality-adjusted human development index: a constructive proposal. World Development, 25(8), 1283-1298.

Holland, M., \& Xavier, C. L. (2005). Dinâmica e competitividade setorial das exportações brasileiras: uma análise de painel para o período recente. Economia e Sociedade Campinas, 14(1), 85-108. https://doi. org/10.20396/rbi.v11i2.8649048.

International Monetary Fund (IMF), P. E. R. (2014). Making difficult choices. Fiscal Monitor. April 2014. Washington DC: International Monetary Fund.

Instituto Brasileiro de Geografia e Estatística (IBGE). (2010). Censo demográfico 2010. Rio de Janeiro: IBGE. https://www.ibge.gov.br/home/estatistica/populacao/censo2000/. Retrieved May 25, 2018.

Instituto Brasileiro de Geografia e Estatística (IBGE). (2000). Censo demográfico 2010. Rio de Janeiro: IBGE. https://censo2010.ibge.gov.br. Retrieved May 25, 2018.

Instituto Brasileiro de Geografia e Estatística (IBGE). (2017). Divisão Regional do Brasil em mesoregiões e microregiões geográficas. Rio de Janeiro: IBGE. https://biblioteca.ibge.gov.br/visualizacao/monog rafias/GEBIS\%20-\%20RJ/DRB/Divisao\%20regional_v01.pdf. Retrieved May 25, 2018.

Kaufmann, D., Kraay, A., \& Mastruzzi, M. (2008). Governance matters VII: Aggregate and individual governance indicators 1996-2007. Washington DC: The World Bank.

Kupek, E., \& Tritany, E. F. (2009). Impact of vaccination against varicella on the reduction of the disease incidence in children and adolescents from Florianópolis, Brazil. Jornal de Pediatria, 85(4), 365-368. 
Leta, F. R., Soares de Mello, J. C. C., Gomes, E. G., \& Meza, L. A. (2005). Métodos de melhora de ordenação em DEA aplicados à avaliação estática de tornos mecânicos. Investigação Operacional, 25(2), 229-242.

Lima, J. F., \& Bidarra, B. S. (2019). Concentração e desigualdade na Região Metropolitana de Curitiba. urbe. Revista Brasileira de Gestão Urbana, 11.

Lüchters, G., \& Menkhoff, L. (1996). Human development as statistical artifact. World development, 24(8), 1385-1392.

Magalhaes, R. C., \& Heller, L. (2018). Assessment of water supply and sanitation plans: History and outlook in the municipality of Belém. Brazil. Water Policy, 20(5), 901-918.

Mahlberg, B., \& Obersteiner, M. (2001). Remeasuring the HDI by data envelopment analysis. Interim report, IR-01-069. Laxenburg: International Institute for Applied Systems Analysis (IIASA).

Makowiecky, S., \& Carneiro Filho, A. A. (2015). Florianópolis: Conjuntos Historicos Urbanos tombados. pdf.

Malul, M., Hadad, Y., \& Ben-Yair, A. (2009). Measuring and ranking of economic, environmental and social efficiency of countries. International Journal of Social Economics, 36, 832-843.

Marchetti, D., \& Wanke, P. (2017). Brazil's rail freight transport: Efficiency analysis using two-stage DEA and cluster-driven public policies. Socio-Economic Planning Sciences, 59, 26-42.

Mariano, E. B., \& Rebelatto, D. A. D. N. (2014). Transformation of wealth produced into quality of life: Analysis of the social efficiency of nation-states with the DEA's triple index approach. Journal of the Operational Research Society, 65(11), 1664-1681.

Mariano, E. B., Sobreiro, V. A., \& do Nascimento Rebelatto, D. A. (2015). Human development and data envelopment analysis: A structured literature review. Omega, 54, 33-49.

Mata Moraes, M., Marin, S. R., \& de Almeida Vieira, C. (2018). Pobreza multidimensional em Santa Catarina (2000-2010): Uma aplicação do método Alkire-Foster. Economia e Desenvolvimento, 30, 7.

Martín, J. C., \& Mendoza, C. (2013). A DEA approach to measure the quality-of-life in the municipalities of the Canary Islands. Social Indicators Research, 113(1), 335-353.

Maurizio, R., \& Vazquez, G. (2016). Distribution effects of the minimum wage in four Latin American countries: Argentina, Brazil, Chile and Uruguay. International Labour Review, 155(1), 97-131.

McGillivray, M. M., \& White, H. H. (1992). Measuring development: A statistical critique of the UNDP's human development index. ISS Working Paper Series/General Series, 135, 1-25.

McGillivray, M., \& White, H. (1993). Measuring development? The UNDP's human development index. Journal of International Development, 5(2), 183-192.

Mcintyre, D., Meheus, F., \& Røttingen, J. A. (2017). What level of domestic government health expenditure should we aspire to for universal health coverage? Health Economics, Policy and Law, 12(2), $125-137$.

Meheus, F., \& McIntyre, D. (2017). Fiscal space for domestic funding of health and other social services. Health Economics, Policy and Law, 12(2), 159-177.

Ministério do Planejamento, Desenvolvimento e Gestão (MPDG). (2010). Despesas Municipais 2010. https ://www.planejamento.gov.br/. Retrieved May 20, 2018.

Monteiro, F. D. S. C., \& Lima, J. P. R. (2017). Regional deindustrialization in Brazil. Nova Economia, 27(2), 247-293.

Morais, P., Miguéis, V. L., \& Camanho, A. S. (2013). Quality of life experienced by human capital: An assessment of European cities. Social Indicators Research, 110(1), 187-206.

Murray, J. L. (1993). Development data constraints and the Human Development Index. In D. G. Westendor \& D. Ghai (Eds.), Monitoring social progress in the 1990's (pp. 40-44). Aldershot: Avebury.

Nardo, M., Saisana M., Saltelli A., Tarantola S., Hoffman A. \& Giovannini, E. (2005) Handbook on constructing composite indicators: Methodology and user guide. OECD Statistics Working Papers.

Noorbakhsh, F. (1998). A modified human development index. World Development, 26(3), 517-528.

Nussbaum, M. C. (2000). Women and human development: The capabilities approach. New York: Cambridge University Press.

OECD. (2008). Handbook on constructing composite indicators: Methodology and user guide. Paris: OECD Publishing.

Osipian, A. L. (2013). Corruption and democracy in Brazil: The Struggle for Accountability: Editors: Power, Timothy J. (Latin American Centre, University of Oxford, 1 Church Walk, Oxford, OX2 6LY, UK. E-mail address: timothy. power@ lac. ox. ac. uk) and Taylor, Matthew M.(School of International Service, American University, 4400 Massachusetts Avenue, NW, Washington, DC 20016, USA. E-mail: mtaylor@ american. edu)(Eds) Notre Dame, IN, University of Notre Dame Press, 2011, 328 pp \$38.00, paperback, ISBN: 13: 978-0-268-03894-6. Journal of Comparative Policy Analysis: Research and Practice, 15(2), 199-202. 
OXFAM Brasil. (2017). Inequalities in Brazil: The divide that unite us. https://www.oxfam.org.br/sites/ default/files/arquivos/relatorio_a_distancia_que_nos_une_en.pdf. Retrieved February 01, 2018.

Pisa, OECD. (2015). PISA: Results in focus. Organisation for economic co-operation and development, OECD.

Prasetyo, A. D., \& Zuhdi, U. (2013). The government expenditure efficiency towards the human development. Procedia Economics and Finance, 5, 615-622.

Raab, R., \& Habib, E. (2007). A productivity growth accounting approach to the ranking of developing and developed nations. The International Journal of Accounting, 42, 396-415.

Raab, R., Kotamraju, P., \& Haag, S. (2000). Efficient provision of child quality of life in less developed countries: conventional development indexes versus a programming approach to development indexes. Socio-Economic Planning Sciences, 34(1), 51-67.

Ramanathan, R. (2006). Evaluating the comparative performance of countries of the Middle East and North Africa: A DEA application. Socio-Economic Planning Sciences, 40(2), 156-167.

Ranis, G., Stewart, F., \& Samman, E. (2006). Human development: beyond the human development index. Journal of Human Development, 7(3), 323-358.

Ravallion, M. (2010). Troubling tradeoffs in the human development index. Washington DC: The World Bank.

Reig-Martínez, E. (2013). Social and economic wellbeing in Europe and the Mediterranean Basin: Building an enlarged human development indicator. Social Indicators Research, 111(2), 527-547.

Ribeiro, K. G., Andrade, L. O. M. D., Aguiar, J. B. D., Moreira, A. E. M. M., \& Frota, A. C. (2018). Educação e saúde em uma região em situação de vulnerabilidade social: avanços e desafios para as políticas públicas. Saúde, Educação: Interface-Comunicação.

Robeyns, I. (2003). Sen's capability approach and gender inequality: selecting relevant capabilities. Feminist economics, 9(2-3), 61-92.

Robeyns, I. (2005). The capability approach: a theoretical survey. Journal of human development, 6(1), 93-117.

Robeyns, I. (2006). The capability approach in practice. Journal of Political Philosophy, 14(3), 351-376.

Rocha, C. (2009). Developments in national policies for food and nutrition security in Brazil. Development Policy Review, 27(1), 51-66.

Sagar, A. D., \& Najam, A. (1998). The human development index: a critical review. Ecological economics, 25(3), 249-264.

Saisana, M., \& Tarantola, S. (2002). State-of-the-art report on current methodologies and practices for composite indicator development. European Commission Joint Research Center (EUR 20408 EN).

Saltelli, A. (2007). Composite indicators between analysis and advocacy. Social Indicators Research, 81(1), $65-77$.

Sayed, H., Hamed, R., Hosny, S. H., \& Abdelhamid, A. H. (2018). Avoiding ranking contradictions in Human Development Index using goal programming. Social Indicators Research, 138(2), 405-442.

Seiford, L. M., \& Zhu, J. (2002). Modeling undesirable factors in efficiency evaluation. European Journal of Operational Research, 142(1), 16-20.

Sen, A. K. (1979). The welfare basis of real income comparisons: a survey. Journal of Economic Literature, $17(1), 1-42$.

Sen, A. K. (1980). Equality of what. In S. M. McMurrin (Ed.), The tanner lectures on human value (pp. 195-220). Salt Lake City: University of Utah Press.

Sen, A. K. (1982). Choice, welfare, and measurement. Oxford: Basil Blackwell.

Sen, A. K. (1988). The concept of development. In H. Chenery \& T. N. Srinivasan (Eds.), Handbooks of Development Economics. North-Holland: Elsevier.

Sen, A. (1999). Development as Freedom. New York: Alfred Knopf.

Sen, A. K. (2009). The idea of justice. Cambridge: Harvard University Press.

Seth, S. (2009). Inequality, interactions, and human development. Journal of Human Development and Capabilities, 10, 375-396.

Seth, S. (2010). A Class of Association Sensitive Multidimensional Welfare Indices, mimeo. Nashville: Vanderblit University.

Sistema IBGE de Recuperação Automática (SIDRA/ibge). (2019). Banco de dados agregados. On-line. www.sidra.ibge.gov.br/bda/acervo/acervo2.Asp. Retrieved February 01, 2018.

Somarriba, N., \& Pena, B. (2009). Synthetic indicators of quality of life in Europe. Social Indicators Research, 94(1), 115-133.

Sousa, R. G., Paulo, E., \& Marôco, J. (2017). Longitudinal factor analysis of public expenditure composition and human development in Brazil after the 1988 constitution. Social Indicators Research, 134(3), 1009-1026. 
Saad-Filho, A. (2015). Social policy for neoliberalism: the Bolsa Família programme in Brazil. Development and Change, 46(6), 1227-1252.

Srinivasan, T. N. (1994). Human development: A new paradigm or reinvention of the wheel? The American Economic Review, 84(2), 238-243.

Stine, R. A. (1995). Graphical interpretation of variance inflation factors. The American Statistician, 49(1), 53-56.

Streeten, P. (1981). First things first: Meeting basic human needs in developing countries. Oxford: Oxford University Press.

Streeten, P. (1994). Human development: Means and ends. American Economic Review, 84(2), $232-237$.

Taner, M. T., Sezen, B., Alpkan, L., \& Aren, S. (2010). Recomputation of UNDP's HDI rankings by data envelopment analysis. St. Petersburg, Russia: International Strategic Management Conference.

Timmons, J. F., \& Garfias, F. (2015). Revealed corruption, taxation, and fiscal accountability: Evidence from Brazil. World Development, 70, 13-27.

Tofallis, C. (2013). An automatic-democratic approach to weight setting for the new human development index. Journal of Population Economics, 26(4), 1325-1345.

UNDP. (1993). Human Development Report 1993. Technical notes. Available from: https://hdr.undp.org/ sites/default/files/reports/222/hdr_1993_en_complete_nostats.pdf. Accessed 10 Dec 2018.

UNDP. (2016). Human development report 2016. Technical notes. Available from: https://hdr.undp.org/ en/2016-report. Accessed 10 Dec 2018.

Varela, P. S., de Andrade Martins, G., \& Fávero, L. P. L. (2010). Production efficiency and financing of public health: An analysis of small municipalities in the state of São Paulo-Brazil. Health Care Management Science, 13(2), 112-123.

Vargas da Cruz, M. J., \& Camargo Rolim, C. F. (2010). The Brazilian automotive industry in the BRICs context: The case of the Metropolitan Region of Curitiba. Cambridge Journal of Regions, Economy and Society, 3(3), 319-334.

Varshney, A. (1998). Democracy, development and the countryside. Cambridge: Cambridge University Press.

Viloria, A., Vasquez, C., \& Nunez, M. (2009). Use of the data envolvent analysis to determine the correct management of the economic resources of a country. In 2009 2nd international conference on adaptive science \& technology (ICAST) (pp. 422-425). IEEE.

Wolff, H., Chong, H., \& Auffhammer, M. (2009). Human development index: Are developing countries misclassified?. Milwaukee, WI: Agricultural and applied economics association annual meeting.

World Bank. (2018). World development indicators. https://databank.worldbank.org. Retrieved February 01, 2018.

Wu, P. C., Fan, C. W., \& Pan, S. C. (2014). Does human development index provide rational development rankings? Evidence from efficiency rankings in super efficiency model. Social Indicators Research, 116(2), 647-658.

Xavier, M. (2010). Polo Tecnológico de Florianópolis: origem e desenvolvimento (p. 176). Florianópolis: Editora Insular.

Yamada, Y., Matui, T., \& Sugiyama, M. (1994). New analysis of efficiency based on DEA. Journal of the Operations Research Society of Japan, 37(2), 158-167.

Yigitcanlar, T., Sabatini-Marques, J., da-Costa, E. M., Kamruzzaman, M., \& Ioppolo, G. (2017). Stimulating technological innovation through incentives: Perceptions of Australian and Brazilian firms. Technological Forecasting and Social Change.

Zhou, P., Ang, B. W., \& Poh, K. L. (2007). A mathematical programming approach to constructing composite indicators. Ecological Economics, 62(2), 291-297.

Zhou, P., Ang, B. W., \& Zhou, D. Q. (2010). Weighting and aggregation in composite indicator construction: A multiplicative optimization approach. Social Indicators Research, 96(1), 169-181.

Publisher's Note Springer Nature remains neutral with regard to jurisdictional claims in published maps and institutional affiliations. 


\section{Affiliations}

\section{Diogo Ferraz ${ }^{1,2,3}$ - Enzo B. Mariano ${ }^{4}$. Daisy Rebelatto ${ }^{1}$. Dominik Hartmann ${ }^{1,2,5}$}

1 Department of Production Engineering, University of São Paulo, Avenida Trabalhador São Carlense, n. 400, São Carlos 13562-190, Brazil

2 Department of Innovation Economics, University of Hohenheim, Wollgrasweg 23, 2nd floor Room 520i, 70599 Stuttgart, Germany

3 Federal Rural University of Amazonia (UFRA), PA-275 s/n Zona Rural, Parauapebas 68515-000, Brazil

4 Department of Production Engineering, São Paulo State University, Avenida Engenheiro Luiz Edmundo Carrijo Coube, 14-01, Núcleo Residencial Presidente Geisel, Bauru 17033360, Brazil

5 Department of Economics and International Relations, Federal University of Santa Catarina (UFSC), Rua Eng. Agronômico Andrei Cristian Ferreira, s/n, Florianópolis 88040-900, Brazil 